\title{
Essay
}

\section{Stopping Above-Cost Predatory Pricing}

\author{
Aaron S. Edlin ${ }^{\dagger}$
}

\section{INTRODUCTION}

Since 1993, when the Supreme Court decided Brooke Group Ltd. v. Brown \& Williamson Tobacco Corp., ${ }^{1}$ no predatory pricing plaintiff has prevailed in a final determination in the federal courts. ${ }^{2}$ This case was a great victory for the Chicago School of antitrust. One leader of that school, then-Professor Frank Easterbrook, once asked whether there are so many theories of predation because it "is a common but variegated phenomenon" or rather "for the same reason that 600 years ago there were a thousand positions on what dragons looked like." ${ }^{3}$ He concluded that predation was much like dragons and that "there is no sufficient reason for antitrust law or the courts to take [predation] seriously." 4

This Essay argues that the decision in Brooke Group was no great day for consumers, for well-functioning markets, or for antitrust law. The Court's reading of the law is unduly narrow and should be revisited. In

$\dagger$ Professor of Economics and Law, University of California Berkeley School of Law. J.D. 1993, Stanford University; Ph.D. 1993, Economics, Stanford University. I am grateful for conversations with and comments from Bruce Ackerman, Ian Ayres, Richard Craswell, Frank Easterbrook, Victor Goldberg, Jeffrey Gordon, Henry Hannsman, Louis Kaplow, Avery Katz, Alvin Klevorick, Michael E. Levine, Barry Nalebuff, Eric Posner, Richard Posner, Michael Riordan, Howard Shalanski, Chris Udry, and workshop participants at Columbia Law School, Harvard Law School, Stanford Law School, the University of Chicago Law School, and Yale Law School. I am also grateful for a Sloan Faculty Fellowship, for the financial support of Columbia Law School, Yale Law School, and the School of Law at UC Berkeley, and for research assistance by Joseph Bartel.

1. 509 U.S. 209 (1993).

2. Patrick Bolton et al., Predatory Pricing: Strategic Theory and Legal Policy, 88 GEO. L.J. 2239, 2241 (2000).

3. Frank H. Easterbrook, Predatory Strategies and Counterstrategies, 48 U. CHI. L. REV. $263,264(1981)$.

4. $I d$. 
particular, there is no compelling reason to restrict predation cases to below-cost pricing, ${ }^{5}$ as above-cost pricing can also hurt consumers by limiting competition. ${ }^{6}$ In cases of monopolization or attempted monopolization, such "above-cost predation" may be more plausible and prevalent than below-cost predation. As a result, this Essay argues that the courts should limit the Brooke Group holding to oligopoly cases like that in which it arose. ${ }^{7}$

The Department of Justice (DOJ) recently sued American Airlines for predatory pricing and predatory expansion of flights on routes to and from its hub at the Dallas-Fort Worth airport. ${ }^{8}$ The DOJ made a plausible case

5. In cases before Brooke Group, the Supreme Court strongly suggested that low-cost pricing was a necessary element in a predation case. However, as the Brooke Group opinion notes, in those two cases, the Court formally reserved the question "whether recovery should ever be available ... when the pricing in question is above some measure of incremental cost." Brooke Group, 509 U.S. at 223 (quoting Matsushita Elec. Indus. v. Zenith Radio Corp., 475 U.S. 574,585 n.9 (1986)). Brooke Group comes the closest to holding that above-cost pricing is per se legal because it unequivocally states that below-cost pricing is a necessary element of predation, whether the predation case is a monopolization case brought under section 2 of the Sherman Act or a price discrimination case brought under the Robinson-Patman Act. $1 d$. at 222-23. One could argue that this conclusion is only dictum because the Court actually ruled that the plaintiff lost its case not because price exceeded cost (the Court upheld the jury finding that price was less than cost), but because the plaintiff failed to prove the second necessary element of predation, the reasonable prospect of recoupment of losses. Such an argument falls flat, however, because saying that a prospect of recoupment is a necessary element presumes that there are losses to be recouped. In short, the entire reasoning of the Court is tied to the idea that predation requires below-cost pricing.

6. This proposition is quite radical in that even economists who believe that predatory pricing is relatively common have generally been content to follow the courts in thinking that the key element of predation is short-run sacrifice by the predator, or even extreme sacrifice (selling below cost). For example, Bolton, Brodley, and Riordan lament the courts' lenient treatment of predators and see the problem primarily as a lack of understanding by courts of the myriad plausible ways that losses can be recouped. Bolton et al., supra note 2 , at 2263 . They therefore outline a variety of proposed elements for predation cases based upon different theories of recoupment and cost measurement but stay within the standard Brooke Group paradigm in which predation entails selling at a loss and later recouping the loss because of reduced future competition. Id. at 2262-74. One recent paper by Spector also shows that above-cost pricing can injure consumers in a differentiated products model by excluding a rival and lowering product diversity. In his model it only lowers overall welfare, however, if the exclusionary pricing involves a short-run sacrifice made in the expectation of future profits. Spector speculates that the connection between "sacrifice" and lower overall welfare is a coincidence that would not generalize to other models. David SPECTOR, DeFINITIONS AND CRITERIA OF PREDatory PRICING (MIT Dep't of Econ., Working Paper No. 01-10, 2001), available at http://papers.ssm.com/paper.taf?abstract_id=262027.

7. Brooke Group was an oligopoly price discrimination case brought under the RobinsonPatman Act. Lower courts have sometimes required a showing of pricing below cost in a monopolization case brought under section 2 of the Sherman Act, but the Supreme Court has never ruled on the matter explicitly in a Sherman Act case. See, e.g., Barry Wright Corp. v. ITT Grinnell Corp., 724 F.2d 227 (1st Cir. 1983). The Court did nonetheless go out of its way in Brooke Group to assert in dictum that the basic standards of judging predation were the same under the monopolization ban as under the price discrimination ban. Brooke Group, 509 U.S. at 224.

8. United States v. AMR Corp., 140 F. Supp. $2 d 1141$ (D. Kan. 2001) (holding that the allegation of predatory expansion of flights amounted to nothing more than a predatory pricing 
that American Airlines had a monopoly over passenger travel into and out of the Dallas-Fort Worth airport, or that it had or was attempting to acquire monopoly power on particular routes. ${ }^{9}$ The DOJ showed that when Vanguard Airlines began flying from Kansas City to Dallas at low fares, American quickly matched fares, lowered prices by over twenty-five percent, and increased the frequency of its flights substantially. Customers saw little reason to fly with Vanguard, given American's response. After Vanguard gave up, however, American raised its fares and reduced its flight frequency. ${ }^{10}$ The DOJ made similar allegations with respect to attempts by Sun Jet International and Western Pacific to enter the Dallas-Fort Worth market. These facts alone, however, do not constitute a case of predatory pricing under Brooke Group.

A successful predatory pricing case under Brooke Group requires showing that American priced below its cost, and also that American stood a reasonable chance of recovering the resulting losses. ${ }^{11}$ American won on summary judgment because the trial court found it was pricing above its variable cost. This Essay argues that the two predatory elements isolated in Brooke Group-below-cost pricing and the possibility of recoupmentmay be sufficient to make out a predatory pricing case, but they should not be necessary.

American Airlines apparently had sufficient advantages to force Vanguard to cancel all its nonstop flights between Dallas-Fort Worth and Kansas City by the end of 1995 without pricing below its cost. ${ }^{12}$ But does this mean that customers were better off without Vanguard?

case and that American defeated allegations of predatory pricing because it priced above its variable cost). The Department of Justice is currently appealing the case.

9. American carries seventy-seven percent of all passengers originating in Dallas-Fort Worth who travel nonstop between Dallas-Fort Worth and another airport, and seventy percent of all passengers who travel nonstop between Dallas-Fort Worth and another airport. Complaint II 20 , AMR Corp. (No. 99-1180), http://www.usdoj.gov/atr/cases/f2400/2438.htm.

10. This chain of events reflects a likely coordination failure by consumers. If most consumers flew Vanguard anyway, all might have benefited from low fares indefinitely. Because no single customer has any appreciable effect on Vanguard's long-term prospects, however, no one acts to keep Vanguard in business.

11. See Brooke Group, 509 U.S. at 222-24. The Court in Brooke Group did not address the question of which measure of cost is relevant. It "declin[ed] to resolve the conflict among the lower courts over the appropriate measure of cost" because both parties agreed that average variable cost was the appropriate measure. $1 d$. at $222 \mathrm{n} .1$.

12. American has many advantages over entrants like Vanguard. To begin with, it has a brand-name reputation that will draw customers at an equal price, or even a premium price, as long as the premium is not too large. Thus, American can fill more planes in a given day than Vanguard, which creates a positive fcedback loop. By offering more flights per day, American has an even larger advantage because of the scheduling convenience for passengers. In addition, its extensive network of flights means that it can offer passengers free tickets to almost anywhere through its frequent flyer programs. These frequent flyer tickets are valuable to customers but inexpensive to American because they are restricted to American's least crowded flights. The advantages of brand name, a convenient flight schedule, and a valuable frequent flyer program mean that at an equal price to Vanguard, American's flights will be fuller. This in turn means that, holding other things equal, American will tend to have a lower per-passenger cost because its 
An incumbent monopoly with a significant cost or noncost advantage over entrants-a situation this Essay argues is common for monopoliescan use these advantages to drive entrants from the market by pricing below their cost, but above its own. ${ }^{13}$ As Part III makes clear, this strategy is quite credible and effective. If the strategy is legal, higher-cost rivals will not even attempt entry, and consumers may never enjoy low prices. If entrants who would price below the monopoly are excluded from the market, consumers are worse off than if the low-cost monopoly did not exist. ${ }^{14}$ This Essay calls such strategies above-cost predation and argues they should violate section 2 of the Sherman Act.

The standard view of predatory pricing is stated clearly by Judge Easterbrook:

Predatory prices are an investment in a future monopoly, a sacrifice of today's profits for tomorrow's. The investment must be recouped. If a monopoly price later is impossible, then the sequence is unprofitable and we may infer that the low price now is not predatory. More importantly, if there can be no "later" in which recoupment could occur, then the consumer is an unambiguous beneficiary even if the current price is less than the cost of production. ${ }^{15}$

fixed costs will be shared over more passengers. American's hub in Dallas also provides American with substantial economies of scope in scheduling flights and combining passengers from various routes. For example, a substantial portion of the passengers on a flight leaving from Dallas to Kansas City (the route Vanguard entered) would be filled with passengers flying to Kansas City through Dallas, but originating in other locales such as Miami. Such "through" passengers make up over fifty percent of traffic in major hubs. See Enforcement Policy Regarding Unfair Exclusionary Conduct in the Air Transportation Industry, 63 Fed. Reg. 17,919, 17,920 (Apr. 10, 1998) [hereinafter Enforcement Policy]. If American can justify flying most of its flights with its through passengers, then the cost to American of flying customers directly from Dallas to Kansas City may be quite low, perhaps even as low as the extra fuel cost and meals. American also enjoys substantial economies of scope and scale in its hub from scheduling airplanes and crews. If a plane or crew is needed to fly to Kansas City at a particular time, it can be scheduled to dovetail with any of hundreds of other incoming flights to Dallas. These various economies may imply that even if American has relatively high costs per airplane and flight crew, it may still enjoy low costs for the marginal or average flight, and very low costs for the marginal or average passenger.

13. A monopoly with a demand advantage (for example, an advantage arising from network effects, frequent flyer programs, or preferences for familiar products) may similarly price near cnough to its own cost to force rivals to sell at a loss if they want to offer an equally attractive package of price and quality.

14. See Easterbrook, supra note 3, at 281 n.40 ("A plan to exclude competition by less efficient rivals is not anti-competitive, and a plan to exclude competition by more efficient rivals is doomed to failure."). Easterbrook's view that excluding higher-cost rivals cannot be anticompetitive is surprising. Even if one takes the total welfare perspective, the model in Part IV shows that excluding a higher-cost rival with the threat of predatory prices lowers total welfare compared with exclusion by low limit prices.

15. A.A. Poultry Farms, Inc. v. Rose Acre Farms, Inc., 881 F.2d 1396, 1401 (7th Cir. 1989). 
The Supreme Court endorsed a more extreme version of this view in Brooke Group in which today's profit sacrifice must entail actually suffering losses, rather than simply failing to maximize profits.

This Essay presents a simple model in which there is no "later." The incumbent monopoly is therefore unwilling to make any sacrifices, so it maximizes short-run profits, but it does so with prices low enough to drive out an entrant. ${ }^{16}$ If the law fails to recognize these low prices as predatory because they are above cost, consumers are the unambiguous losers, not the unambiguous beneficiaries that Easterbrook and the Supreme Court expect. Existing predation law means the potential entrant will, in fact, not enter, and consumers will always pay high prices to the incumbent. The predatory problem occurs not "later," after exit, but "sooner," before entry. The key problem is ex ante. This shift in temporal focus is a critical part of this Essay's argument.

Then-Judge Breyer cautioned against this approach and justified the exclusion of above-cost pricing from predatory pricing prohibitions on the ground that otherwise we cast away "birds in hand" in favor of more speculative "birds in the bush." 17 One problem with this reasoning is that the benefits of low pricing (the supposed "birds in hand") may only be temporary if entrants like Vanguard or Barry Wright are driven from the market. Of still more concern, if firms anticipate being driven from the market shortly after entry, they will typically not enter at all. If this occurs, even the transitory gains that Judge Breyer expected will not appear. Judge Breyer may never get his "birds in hand."

In the spirit of Williamson and Baumol, this Essay proposes a "dynamic" standard for adjudicating predation: In markets where an incumbent monopoly enjoys significant advantages over potential entrants, but another firm enters and provides buyers with a substantial discount, the monopoly should be prevented from responding with substantial price cuts or significant product enhancements until the entrant has had a reasonable time to recover its entry costs and become viable, or until the entrant's share grows enough so that the monopoly loses its dominance. ${ }^{18}$ For the

16. Spector demonstrates a similar phenomenon in a one-period differentiated products market. See SPECTOR, supra note 6.

17. Barry Wright Co. v. ITT Grinnell Co., 724 F.2d 227, 234 (1st Cir. 1984). Barry Wright entered the market producing mechanical snubbers for nuclear power plants, but (after some delays) lost its only customer, ITT Grinnell, to Pacific, which offered Grinnell a steep discount.

18. According to the classification scheme of Craswell and Fratrik, this proposal would be a "dynamic" standard because it is focused on changes in conduct over time in response to entry and exit. Richard Craswell \& Mark R. Fratrik, Predatory Pricing Theory Applied: The Case of Supermarkets vs. Warehouse Stores, 36 CASE W. RES. L. REV. 1, 6 (1985). The dynamic standards previously proposed by Williamson and Baumol are similar in spirit, but their specifics differ in important ways. This proposal is substantially stricter than Williamson's and has a better legal foundation and better economic consequences than Baumol's. See Oliver E. Williamson, Predatory Pricing: A Strategic and Welfare Analysis, 87 YALE L.J. 284 (1977); William J. Baumol, Quasi-Permanence of Price Reductions: A Policy for Prevention of Predatory Pricing, 
sake of concreteness in application, this Essay usually assumes that if an entrant prices twenty percent below an incumbent monopoly, the incumbent's prices will be frozen for twelve to eighteen months. ${ }^{19}$ If the incumbent does not observe these strictures, as American Airlines did not, then the entrant under this proposal can sue successfully for predatory pricing without the need to demonstrate below-cost pricing or the opportunity for recoupment.

This Essay argues that this rule is a sensible interpretation of section 2 of the Sherman Act and that it is consistent with the basic thrust of monopolization doctrine. This predatory pricing rule encourages the incumbent to charge low prices from the start in order to discourage entry. ${ }^{20}$ Under this rule, if American Airlines, for example, had wanted to discourage Vanguard from entering, it would have had to charge the low prices that it ultimately used to drive Vanguard out of the market even before Vanguard entered. Since it is never clear when an entrant will turn up, American would have to charge low prices all the time. Baumol's alternative predatory pricing rule, by contrast, which required price reductions to be quasi-permanent, aimed to eliminate the high-price period of recoupment. Baumol's rule would not provide any incentive to price low before entry because it creates no link between post-entry and pre-entry prices. $^{21}$

This Essay's predation rule means that matching competitors' prices after entry (if there is entry) is no longer a cheap substitute for actually charging low prices in the first place..$^{22}$ If the incumbent's prices are still high enough to invite entry, under this rule, firms will enter if they can profitably survive while charging prices twenty percent below the monopoly's current prices. The entrant would not have to survive pricing lower than the monopoly could price in reaction to entry. Under this rule, then, firms that would otherwise fear being driven from the market with above-cost predation can enter profitably.

89 YALE L.J. I (1979). Baumol's and Williamson's proposals are discussed and compared to this Essay's proposal in Part VII.

19. The exact operationalization of the rule (twenty percent threshold and twelve to eighteen months duration) could vary by industry or be decided on a case-by-case basis. The price freeze might also be adjusted for inflation in periods of high inflation or for substantial industry-specific price trends.

20. Judges and commentators frequently justify restrictive tests for predatory pricing because they fear that more inclusive tests would ban such limit-pricing behavior. See Barry Wright, 724 F.2d at 231-32; Philip Areeda \& Donald F. Tumer, Predatory Pricing and Related Practices Under Section 2 of the Sherman Act, 88 HARV. L. REV. 697, 699-700 (1975).

21. Baumol, supra note 18.

22. For generally related arguments, see Aaron S. Edlin, Do Guaranteed-Low-Price Policies Guarantee High Prices, and Can Antitrust Rise to the Challenge?, 111 HARV. L. REV. 528 (1997), which argues that guaranteed-low-price policies are a good substitute for actually charging low prices because committing to match price cuts discourages rivals from cutting prices and preserves market share in the rare event that rivals do so nonetheless. 
Consumers get dual benefits under the proposed predatory pricing rule: (1) Incumbents charge lower prices in order to limit entry, and (2) there is more entry at whatever price incumbents choose than there would be at the same price under Brooke Group. Not everyone benefits from such a rule, of course. The incumbent monopoly suffers lower profits while it charges low limit prices, and if entry does occur, the incumbent may be unable to respond in a profit-maximizing way. The consumer surplus gains from low limit pricing will generally exceed the losses to the incumbent before entry. ${ }^{23}$ Overall, however, the social welfare consequences remain ambiguous because if the incumbent's lower limit prices do not discourage all entry, firms protected by the price freeze will sometimes enter despite having higher costs than the incumbent. Consumers would receive a second boon from the entry of these firms-since prices would be lowered-but in some cases profit losses could exceed consumers' gains.

The proposal advances consumer welfare, which has historically been the core goal of antitrust case law. ${ }^{24}$ It stands a good chance of improving

23. That is, when price exceeds marginal cost, a drop in price as part of limit pricing creates net benefits because extra output is produced and sold with a value in excess of cost.

24. Many antitrust cases stress the primacy of consumer welfare. For example, the Court has written that "the end sought was the prevention of restraints ... which... raise prices or otherwise control the market to the detriment of purchasers or consumers of goods and services." Apex Hosiery Co. v. Leader, 310 U.S. 469, 493 (1940). Although Professor Easterbrook's scholarship argues for a total welfare standard, Judge Easterbrook's opinion in A.A. Poultry Farms, Inc. v. Rose Acre Farms, Inc. asserts that a "[p]rice less than cost today, followed by the competitive price tomorrow, bestows a gift on consumers. Because antitrust laws are designed for the benefit of consumers, not competitors, a gift of this kind is not actionable." 881 F.2d 1396, 1401 (7th Cir. 1989). The Supreme Court endorses this view in Brooke Group, arguing that prices below cost are not problematic from an antitrust perspective, even though they are allocatively inefficient, because such prices increase consumer welfare. Brooke Group Ltd. v. Brown \& Williamson Tobacco Corp., 509 U.S. 209, 224 (1993). Hence, these prices are only predatory, and only violate the antitrust laws, if there is the prospect of a later recoupment period when prices are high. Id. The Court wrote that "[a]lthough unsuccessful predatory pricing may encourage some inefficient substitution toward the product being sold at less than its cost, unsuccessful predation is in general a boon to consumers," and for that reason does not violate the antitrust laws. Id. This reasoning in Brooke Group was later picked up by the Ninth Circuit. Rebel Oil Co. v. Atl. Richfield Co., 51 F.3d 1421, 1433-34 (9th Cir. 1995). These arguments in favor of adding a recoupment clcment to the "price less than cost" element implicitly presume that bans on predation seek to protect consumer welfare, not total welfare.

Other antitrust cases and commentators also support consumer welfare as the primary goal of antitrust. See FTC v. Staples, Inc., 970 F. Supp. 1066 (D.D.C. 1997) (dismissing efficiency gains that are not passed on to consumers); Robert H. Lande, Wealth Transfers as the Original and Primary Concern of Antitrust: The Efficiency Interpretation Challenged, 34 HASTINGS L.J. 65, 68 (1982) (finding the major goal of antitrust laws to be the prevention of unfair wealth redistribution "from consumers to firms with market power").

The claim here is not that low prices are, should be, or have been the exclusive goal of antitrust law. Historically, the second goal of antitrust has not, however, been to promote low costs, but rather to oppose concentration even where concentration might lower costs and prices. Justice Brandeis, for example, argued that one can either have great concentrations of power and wealth or democracy, but not both. See, e.g., JOSEPH R. CONLIN, THE MORROW BOOK OF QUOTATIONS IN AMERICAN HISTORY 48 (1984) (quoting Justice Brandeis's statement that "we can have democracy in this country or we can have great wealth concentrated in the hands of a few, but we can't have both"). In Brown Shoe, the Supreme Court noted that "we cannot fail to 
overall welfare as well, a goal many commentators advance, ${ }^{25}$ although the possibility of encouraging high-cost entrants could lower overall welfare. ${ }^{26}$ More restrictive variants might be more certain to improve overall welfare,

recognize Congress's desire to promote competition through the protection of viable, small, locally owned businesses. Congress appreciated that occasional higher costs and prices might result from the maintenance of fragmented industries and markets." Brown Shoe Co. v. United States, 370 U.S. 294, 344 (1962). The Brown Shoe Court previously had observed that the illegal merger of Brown Shoe with Kinney would allow the integrated companies to "market their own brands at prices below those of competing independent retailers." Id. Lower costs by themselves have rarely, if ever, been the deciding factor in any case.

Others have also seen noneconomic political goals as relevant. See, e.g., Robert Pitofsky, The Political Content of Antitrust, 127 U. PA. L. REV. 1051 (1979); see also Thomas J. DiLorenzo, The Origins of Antitrust: An Interest-Group Perspective, 5 INT'L REV. L. \& ECON. 73, 74-76 (1985) (interpreting the Sherman Act as interest-group legislation designed to transfer wealth from big business to small merchants and farmers); Paul L. Joskow \& Alvin K. Klevorick, A Framework for Analyzing Predatory Pricing Policy, 89 Y ALE L.J. 213, 220 (1979) (arguing that "[t]he primary objective of antitrust policy is to promote full and fair market competition and to reap the benefits that competition brings with it"); David Millon, The Sherman Act and the Balance of Power, 61 S. CAL. L. REv. 1219, 1287-92 (1988) (viewing the original purpose of the Sherman Act to be the protection of democratic institutions from concentrated economic power).

25. Then-Professor Robert Bork, for example, championed total wealth maximization (the sum of producer and consumer surplus) as the goal of antitrust, although he confusingly labeled this goal "consumer welfare" on the ground that every producer is ultimately owned by consumers. ROBERT H. BORK. THE ANTITRUST PARADOX 107-15 (The Free Press 1993) (1978). Bork writes, "A consideration of the virtues appropriate to law as law demonstrates that the only legitimate goal of antitrust is the maximization of consumer welfare." Id. at 7; see also id. at 51 ("The only legitimate goal of American antitrust is the maximization of consumer welfare."). Richard Posner also embraces a total-wealth-maximization goal. See RICHARD A. POSNER, ANTITRUST LAW: AN ECONOMIC PERSPECTIVE 8-22 (1976). Kaplow and Shavell support the wealth-maximization goal for all law (other than tax law). See Louis Kaplow \& Steven Shavell, Why the Legal System Is Less Efficient than the Income Tax in Redistributing Income, $23 \mathrm{~J}$. LEGAL STUD. 667 (1994).

Despite the wish of economists and their fellow travelers that the goal of antitrust be to promote overall efficiency, neither case law nor legislative history stands for the proposition that overall economic welfare or wealth maximization trumps low prices. Despite the admittedly enormous recent influence of economics on the courts, cases that take a position on the issue stand for the contrary proposition. E.g., Staples, 970 F. Supp. 1066 (refusing to count efficiency gains not passed on to consumers). It may be fortunate in some ways that courts have not sought to maximize overall welfare because once one widens the scope of antitrust concerns beyond prices in order to evaluate overall social welfare, one confronts an impossible tangle of how to evaluate social welfare or societal wealth in a world rife with market failures. Cartels and other antitrust problems are by no means the only reasons, and not even the primary reasons, that prices deviate from marginal cost. Unions, government regulation, environmental externalities, accidents and other nonenvironmental externalities, search costs, agency costs and other cases of asymmetric or impacted information, opportunism, and irrational decisionmaking all cause prices to deviate from marginal cost. In such a world, even if one could be sure that a given antitrust rule would increase producer and consumer surplus in one market, it might lower overall welfare because true social costs do not determine supply in that market or one related to it.

26. Proper determination of overall welfare consequences should consider cases where entry occurs because of this rule that would not otherwise occur. In such cases, overall welfare increases because prices are substantially lower than they would be otherwise. Prices are lower, first, by the amount that the incumbent lowered prices to limit entry, and second, by the entrant's discount, which needs to be at least twenty percent to secure the price freeze. The reduction in inefficiency from these low prices could exceed the social costs arising from inefficient production during the post-entry phase. Even if overall welfare is lowered after entry, however, this loss should be multiplied by the probability of entry and compared with the efficiency gains that arose before entry, because prices were lower during that phase. 
but only by sacrificing some of the consumer gains from higher-cost entrants. ${ }^{27}$

The rule advocated here also presents fewer administrative costs than other "dynamic" alternatives. Areeda and Turner considered and rejected one such alternative rule in which an incumbent monopoly could match but not beat the prices of an entrant. ${ }^{28}$ They argued that such a policy would be impossible to administer because of the great difficulty of distinguishing matching from beating in common situations where quality and consumer preferences are tricky to evaluate ${ }^{29}$ This Essay's proposal forbids price cuts even when the cuts do not entail price-beating. The price freeze makes the policy significantly more effective in that the incumbent will price much lower to prevent entry because entry leads to such stringent restrictions. In addition, the restrictions are somewhat easier to monitor than a qualityadjusted matching restriction, because a temporary freeze on price reductions or quality advances does not require a comparison of the entrant's and rivals' products under some hypothetical consumer's preferences. Nor will small errors in adjudication spoil the impact of the policy. If the incumbent monopoly can get away with a small price reduction or quality enhancement, this will not ruin an entrant's chances. After all, to trigger the price freeze, the entrant must price substantially below the incumbent. ${ }^{30}$ In contrast, allowing American to match Vanguard's fares, as it did, when consumers have even a slight preference to fly American, could entirely squelch an entrant's chances.

Part II explains and critiques existing predatory pricing doctrine. Part III then presents a simple model with above-cost predation by a low-cost monopoly. Part IV puts forward a typology of scenarios where allegations of predatory pricing might arise and suggests that existing doctrine cannot reasonably handle them all. Part $\mathrm{V}$ proposes a new category of predatory pricing claim. Part VI compares existing doctrine with the Essay's proposed rule in the model considered in Part III and illustrates the advantages of this Essay's proposal. Part VII compares this Essay's predation rule to proposals made by Baumol and Williamson. Part VIII applies this Essay's rule to several concrete cases. Part IX concludes.

27. For example, a more moderate approach would require the plaintiff in a predatory pricing case to prove that (1) it has sufficiently low cost and price to bring overall value to the market and (2) it would likely not have entered if it knew the incumbent would respond as the incumbent did. Such a standard allows the possibility of an above-cost predation case, but it only protects firms whose entry improves overall social welfare.

28. Areeda \& Turner, supra note 20 , at 707-08.

29. If consumers are heterogeneous, the concept is inherently ill-defined because matching for one buyer will entail beating for another.

30. Admittedly, the administrative gain from the restrictions being relatively easy to monitor may be somewhat illusory because the twenty percent discount threshold to trigger the price freeze should really be quality-adjusted. 


\section{PRedatory PRICING Doctrine}

In this Part, I explain the state of current predation law, its rationales, and how we got here. If a firm uses predatory pricing to maintain a monopoly or in an attempt to gain a monopoly-the kind of predation I consider in this Essay-it can be attacked under section 2 of the Sherman Act. If the predatory pricing simply lessens competition without creating or maintaining a monopoly, it may still be illegal if the predatory prices are discriminatory-in that case, suits can be brought under section 2(a) of the Clayton Act, as amended by the Robinson-Patman Act. ${ }^{31}$ Courts have generally not distinguished between these two acts when deciding whether prices are predatory. I argue, however, for a stricter rule against predatory pricing in the case of monopolies, a rule that encompasses the possibility of above-cost predation.

\section{A. Monopolization Generally}

From the face of the language in section 2 of the Sherman Act, the statute might simply ban all monopoly. Yet, probably since Standard Oil Co. v. United States, ${ }^{32}$ and certainly since Alcoa, ${ }^{33}$ all have agreed that something more than monopoly is needed to fall within section 2 's prohibitions. $^{34}$

A firm must do something bad to violate section 2. As stated in Grinnell, monopolization entails the possession of monopoly power in the relevant market together with "the willful acquisition or maintenance of that power as distinguished from growth or development as a consequence of a superior product, business acumen, or historical accident." ${ }^{35}$ Courts focus on finding "exclusionary" practices that defeat competition on the merits. ${ }^{36}$ Unlike the actus reus requirement in the rest of criminal law, this requirement is almost entirely pragmatic.

31. Sherman Anti-Trust Act, 15 U.S.C. §§ 1-2 (1994); Clayton Act, 15 U.S.C. $\S \S 12-13$. The Federal Trade Commission can also attack predatory pricing under section 5 of the Federal Trade Commission Act, 15 U.S.C. $\$ 45$, provided the alleged violation concerns goods (not services) traded in interstate commerce. Pricing on such goods that would violate section 1 or section 2 of the Sherman Act or section 2(a) of the Clayton Act will necessarily violate section 5 of the FTC Act. Suits may also be brought under section 1 of the Sherman Act in cases of conspiracy. See Matsushita Elec. Indus. v. Zenith Radio Corp., 475 U.S. 574 (1986).

32. 221 U.S. 1 (1911).

33. United States v. Aluminum Co. of Am., 148 F.2d 416 ( $2 d$ Cir. 1945).

34. Some have, of course, proposed changing the law. For example, the late Senator Philip Hart introduced a bill in the 1970s that would have made it no defense in a civil monopolization action for a defendant to assert that its monopoly was "due to superior product, business acumen, or historic accident." BORK, supra note 25 , at 6 n.*.

35. United States v. Grinnell Corp., 384 U.S. 563, 570-71 (1966).

36. Competition on the merits is one of the touchstone goals of antitrust, as it is thought to enhance consumer welfare. See, e.g., Brooke Group Ltd. v. Brown \& Williamson Tobacco Corp., 
A simple static story that every antitrust teacher tells makes clear the pragmatic reasons why monopoly per se should not create a violation without allowing the defense of superior skill, business acumen, or the like. If a firm achieves monopoly because its superior skill allows it to offer a more attractive package than rivals-higher quality at lower cost-this is no threat to anyone except to those rivals whose goods we are better off without. Consumers benefit from the monopoly offering such an attractive package.

In the standard view, superior skill will not confer on the monopoly the ability to exploit customers by raising price unreasonably. Consider the case where superior skill constitutes the ability to produce a homogeneous good at a cost below that of rivals. If the monopoly raises price above the cost of its rivals or potential rivals, then they will actively produce and sell at lower prices. The monopoly may raise price above its own costs without losing its monopoly, earning significant profits, but only so long as it does not raise price above its rivals' costs and thereby invite their entry. This limited profit-taking by the monopoly is neither unreasonable nor injurious to consumer welfare, nor is it inefficient when compared to the practical alternatives. As then-Professor Bork wrote,

If the leading firms in a concentrated industry are restricting their output in order to obtain prices above the competitive level, their efficiencies must be sufficiently superior to that of all actual and potential rivals to offset that behavior. Were this not so, rivals would be enabled to expand their market shares because of the abnormally high prices and would thus deconcentrate the industry. Market rivalry thus automatically weighs the respective influences of efficiency and output restriction and arrives at the firm sizes and industry structures that serve consumers best. ${ }^{37}$

If the monopoly charges a price in excess of its marginal cost, the monopoly creates an inefficiency compared to an ideal world because output is restricted. This ex post inefficiency, however, provides a return to skill and innovation. ${ }^{38}$ Without a significant return to such innovations, our economy would surely suffer from a pervasive deficit of skill and innovations. Even if we neglect these innovation disincentives, courts might still be unable to improve the situation because they are unsuited to the price regulator's task of determining cost. Even administrative agencies

509 U.S. 209, 223 (1993); see also United States v. United Shoe Mach. Corp., 110 F. Supp. 295 (D. Mass. 1953), aff d per curiam, 347 U.S. 521 (1954); Areeda \& Tumer, supra note 20.

37. Robert H. Bork, Separate Statement, Report of the White House Task Force on Antitrust Policy, ANTITRUST L. \& ECON. REV., Winter 1968, at 54.

38. 3 Phillip AREEDA \& HeRBERT HovenKamP, ANTITRUST LaW II 720a, at 254-55 (rev. ed. 1996). 
dedicated to regulation have no miracle cure to the above problem. If they set price equal to cost, firms have no incentive to reduce costs and enormous incentives to misstate their costs through cross-subsidy or accounting artifices. ${ }^{39}$

For good reason, then, monopolization under section 2 requires that the monopoly retain or gain its monopoly power through some exclusionary device other than competition on the merits. The question is when and if price cutting should be seen as such an exclusionary device.

\section{B. Predatory Pricing}

Charging low prices would not seem to qualify as a bad act under the antitrust laws. Indeed, low prices are the primary goal of antitrust, and competition is properly seen as a means to the end of low prices.

The paradigmatic predatory pricing claim is that the firm charges abnormally low prices in order to drive rivals from the market or to chasten them. These low prices do not reflect competition on the merits. Rather, they will only be available temporarily until the rivals exit - after that, the firm plans to charge high prices. ${ }^{40}$ The challenge for courts has been to find a way to distinguish anticompetitive low prices from procompetitive low prices. Rivals will, after all, always complain about low prices so long as courts will give them an audience. When setting a legal standard intended to distinguish procompetitive from anticompetitive low prices, courts must balance the possibility of being underinclusive against that of being overinclusive. The probabilities of these two types of errors depend, of course, upon the underlying plausibility of predatory pricing.

Since McGee, Chicago School critics have been quick to point out that to drive out an equally efficient rival, the predator must charge a price below cost, and that to do this, the predator must serve the whole market by itself at an unremunerative price. ${ }^{41}$ Losses for the predator could be staggering, while the prey could cut back its own output and limit its losses. Critics like Bork have contended that if predation is possible at all, it requires that the predator have a huge war chest. They further point out that if the predator subsequently raises prices, the prey, together with other rivals, can return in force. Bork, for example, argues that if rivals are to be driven from the market, "[l]osses during a price war will be proportionally

39. 3 id. Il $720 \mathrm{~b}$, at $256-58$.

40. See generally Brooke Group, 509 U.S. 209; Rebel Oil Co. v. Atl. Richfield Co., 51 F.3d 1421 (9th Cir. 1995); Barry Wright Corp. v. ITT Grinnell Corp., 724 F.2d 227 (1st Cir. 1984).

41. See John S. McGee, Predatory Price Cutting: The Standard Oil (N.J.) Case, 1 J.L. \& ECON. 137 (1958). Plaintiffs avoid arguing that the larger firm is able to charge low prices because it has low costs since this argument tends to favor the idea that the low prices simply reflect competition on the merits. 
higher for the predator because he faces the necessity of expanding his output at ever higher costs, while the victim not only will not expand output but has the option of reducing it and so decreasing his costs." ${ }^{42}$ According to this view, we should not expect predatory pricing to happen very frequently (recall Easterbrook's comparison to dragons), and, therefore, the legal elements necessary to make out a predatory pricing case should be very stringent. ${ }^{43}$

The Chicago School criticism, which emerged among legal academics between the 1950s and the 1980s, was a reaction against the courts' sympathy toward predatory pricing claims. Particularly galling were the Robinson-Patman cases, which found liability for anticompetitive predatory price discrimination without requiring probable or actual monopolization. ${ }^{44}$ In these cases, the low prices seemed more likely to injure competitors than competition and consumers. Utah Pie is the leading example; today it stands among the Court's most castigated antitrust opinions, as Brooke Group and Rose Acre point out. ${ }^{45}$ Utah Pie, which dominated its local Salt Lake City market, alleged predatory pricing and sued several national pie companies that were making inroads into the Utah market. The price war started by the national firms in Utah had a dramatic adverse effect upon Utah Pie, as its share fell from $66.5 \%$ to $45.4 \%$ during the period of the complaint. The Court agreed with Utah Pie that it was the victim of predation. The price war did not, however, drive Utah Pie out of the market, nor even make the firm unprofitable. Looking back from today's vantage point, the facts suggest vigorous price competition that benefited consumers in the short run and probably the long run as well. Lower court decisions in Robinson-Patman cases in the 1950s and 1960s also seemed to protect competitors, not competition. ${ }^{46}$ As late as 1989 , the Robinson-Patman precedents meant that even though Judge Easterbrook felt that Rose Acre actually deserved an "antitrust medal" instead of a fine, he could not,

42. BORK, supra note 25 , at 149.

43. Easterbrook, supra note 3, at 264; see also Gary S. Becker \& Kevin M. Murphy, Rethinking Antitrust, WALL ST. J., Feb. 26, 2001, at A22.

44. See, e.g., Utah Pie Co. v. Continental Baking Co., 386 U.S. 685 (1967); Moore v. Mead's Fine Bread Co., 348 U.S. 115 (1954).

45. Brooke Group Ltd. v. Brown \& Williamson Tobacco Corp., 509 U.S. 209, 221 (1993); A.A. Poultry Farms, Inc. v. Rose Acre Farms, Inc., 881 F.2d 1396, 1404 (7th Cir. 1989).

46. See, e.g., Atlas Bldg. Prods. Co. v. Diamond Block \& Gravel Co., 269 F.2d 950 (10th Cir. 1959); Md. Baking Co. v. FTC, 243 F.2d 716 (4th Cir. 1957). Even the decision in Brown Shoe Co. $v$. United States, 370 U.S. 294, 344 (1962), which famously asserted that "it is competition, not competitors, which the Act protects," was only paying lip service to that sentiment. In fact, the Court protected competitors in Brown Shoe. Even though the Court recognized that "[ $t$ ] retail outlets of integrated companies . . . can market their own brands at prices below those of competing independent retailers," the Court also acknowledged "Congress' desire to promote competition through the protection of viable, small, locally owned businesses," even at the expense of "occasional higher costs and prices [that] might result from the maintenance of fragmented industries and markets." Id. Hence, the Court banned the integration of Brown Shoe with Kinney. Id. at 346. 
consistent with these precedents, rule that Rose Acre's pricing was legal on the ground that it was procompetitive. ${ }^{47}$ Instead, Easterbrook felt forced to declare its pricing legal on the ground that it was nondiscriminatory (essentially, a technicality).

The Chicago School's critique of predatory pricing cases was finally heard loud and clear by the Supreme Court in Matsushita ${ }^{48}$ and Brooke Group. ${ }^{49}$ If the critique had force when a single firm monopolized an industry, it seemed damning in Matsushita and Brooke Group. In those cases, even if the alleged predation were successful, many firms would be left in the market. In Matsushita, this meant that competitive prices would be likely after the predatory period, so the firms would find recoupment of their losses impossible. In Brooke Group, this problem was accentuated in the eyes of the Court because the alleged losses during the predatory period were concentrated in one firm, whereas any unlikely gains would be divided among several.

In Matsushita, the Court adopted the skepticism of Easterbrook, Bork, and other adherents of the Chicago School toward the plausibility of predatory pricing. The Court cited these scholars extensively, quoting Easterbrook to the effect that " "[t]he predator must make a substantial investment with no assurance that it will pay off.", 50 The Court concluded that "predatory pricing schemes are rarely tried, and even more rarely successful." 51 Under the Court's analysis, predation by a single monopoly firm is exceedingly difficult, much more so by a group acting in concert, as alleged in Matsushita. The defendants won on summary judgment because the trial court could not infer that the defendants would do something that the Court thought economically senseless.

Brooke Group quickly followed Matsushita and laid down a test intended to make a clear distinction between procompetitive and anticompetitive low pricing. ${ }^{52}$ Predatory pricing under Brooke Group requires (1) below-cost pricing (instead of merely non-profit-maximizing behavior) and (2) the prospect of recoupment of the resulting losses. Under the Court's theory, banning prices that exceed cost would protect competitors and deny consumers the benefits of buying at low prices, rather than enhance competition or protect consumers from future exploitation. The Court wrote:

47. Before finding the technical "out" that Rose Acre's prices were not legally discriminatory, Easterbrook reasoned that the Robinson-Patman cases "drive[] us almost to the point of reversing the district court" and ruling in favor of the plaintiff. A.A. Poultry Farms, 881 F.2d at 1406 .

48. Matsushita Elec. Indus. v. Zenith Radio Corp., 475 U.S. 574 (1986).

49. 509 U.S. 209.

50. Matsushita Elec. Indus., 475 U.S. at 589 (quoting Easterbrook, supra note 3, at 268).

51. Id.

52. Brooke Group, 509 U.S. at 223. 
As a general rule, the exclusionary effect of prices above a relevant measure of cost either reflects the lower cost structure of the alleged predator, and so represents competition on the merits, or is beyond the practical ability of a judicial tribunal to control without courting intolerable risks of chilling legitimate price cutting. ${ }^{53}$

The Court also quoted Cargill v. Monfort of Colorado, stating that " " $t$ t]o hold that the antitrust laws protect competitors from the loss of profits due to such price competition would, in effect, render illegal any decision by a firm to cut prices in order to increase market share,"' a " "perverse result" " that the antitrust laws do not require. ${ }^{54}$ The recoupment element can be explained as a filter, so that in industries whose competitive structure makes recoupment exceedingly unlikely, courts do not need to struggle with the price-cost determination. This explanation does not, however, explain why the prospect of recoupment could not be inferred from a finding of below-cost pricing, such as in the jury finding upheld in Brooke Group. Alternatively, the recoupment requirement might prevent punishing firms that irrationally lower prices when recoupment is not possible, or provide a backstop rule in case the jury or the court errs in its price-cost comparison.

The Supreme Court in Brooke Group went out of its way to state that the elements of a predatory pricing case are the same for a price discrimination case under section 2(a) of the Robinson-Patman Act as for a monopolization case under section 2 of the Sherman Act. ${ }^{55}$ The analysis of the case of a low-cost monopoly in the next Part, however, suggests that the Court's position is more tenable for the oligopoly case considered in Brooke Group than for a monopoly case under section 2 of the Sherman Act.

\section{ABOVE-COST PREDATION BY A LOW-COST MONOPOLY}

This Part argues that in a market where a monopoly has cost or other advantages over entrants, the Brooke Group rule could lead to adverse welfare consequences. At worst, it could allow a monopoly to charge high prices perpetually, never facing an entrant.

Economists such as Ordover, Klevorick, and Bolton, Brodley, and Riordan commonly write that the "Chicago" view that price predation is likely to be unprofitable is correct in simple market settings, but that in more complex, realistic market situations, such as those with imperfect

53. Id.

54. Id. (quoting Cargill, Inc. v. Monfort of Colorado, Inc., 479 U.S. 104, 116 (1986)).

55. Of course, in a price discrimination case, the plaintiff must demonstrate price discrimination, and in a monopolization case, monopoly power. 
information about costs or about market toughness, aggressive pricing can yield significant long-run benefits to the incumbent firm. ${ }^{56}$ My view is that one reason that two decades of information-theoretical results in economics have not had as much influence on the courts as they should is that they are relatively complex. ${ }^{57}$

This Essay presents a much simpler explanation of why predation can be profitable: When the incumbent has lower costs than entrants, it can drive them from the market by pricing below their cost, but above its own. Without any asymmetric information between the incumbent and a firm considering entry, the potential entrant will not enter in equilibrium, and predation never actually occurs. ${ }^{58}$ In this view, on the rare occasions that courts observe predation, it is best explained as a mistake by the entrant. Much of the economics literature is about understanding the nature of this "mistake" and recasting it as a rational response by the entrant to a lack of information about the market (e.g., low demand) or the incumbent (who may in fact have lower-than-average costs). This Essay is not concerned with modeling or understanding such "mistakes," but rather with proposing a legal definition of predation that encourages entry whenever a firm can give consumers a better deal than they are currently getting.

Below I present a model in which the incumbent has lower costs than the entrant, and the entrant knows this. Predation occurs only offequilibrium under the existing cost-based interpretation of the Sherman Act (i.e., only by mistake). In equilibrium, the fear of predatory pricing prevents an entrant from entering. The predatory pricing definition proposed in Part III, in contrast, protects the entrant and improves consumer welfare.

56. See, e.g., Janusz A. Ordover, Predatory Pricing, in The New PalgRave Dictionary of ECONOMICS AND THE Law 77, 79 (Peter Newman ed., 1998); Alvin Klevorick, The Current State of the Law and Economics of Predatory Pricing, 83 AM. ECON. REV. PAPERS \& PROC. 162 (1993); Bolton et al., supra note 2. For examples from the literatures to which they refer that formally model rational predatory pricing strategies, see generally David M. Kreps \& Robert Wilson, Reputation and Imperfect Information, 27 J. ECON. THEORY 253 (1981); Paul Milgrom \& John Roberts, Limit Pricing and Entry Under Incomplete Information: An Equilibrium Analysis, 50 ECONOMETRICA 443 (1982) [hereinafter Milgrom \& Roberts, Limit Pricing]; and Paul Milgrom \& John Roberts, Predation, Reputation, and Entry Deterrence, 27 J. ECON. THEORY 280 (1982) [hereinafter Milgrom \& Roberts, Predation]. See also David M. Kreps et al., Rational Cooperation in the Finitely Repeated Prisoners' Dilemma, 27 J. ECON. THEORY 245 (1982).

57. Klevorick demonstrates the utter lack of influence of modern economics on the courts by supplementing his considerable reading with a search of all predatory pricing cases for the names of prominent authors (Jean Tirole, David Kreps, Robert Wilson, Paul Milgrom, John Roberts, and Garth Saloner) and for key words from this literature (deep pocket, reputation, signaling, and asymmetric information), which came up empty. His search revealed no influence. Klevorick, supra note 56, at 162.

58. This model is consistent with the Chicago School's view of the rareness of predation, although it is worth noting that Bolton, Brodley, and Riordan have recently challenged the factual accuracy of that claim. Bolton et al., supra note 2, at 2249. 
The model is a full information model with two time periods..$^{59}$ During the first stage, the incumbent monopoly chooses a price $p_{l}$, cognizant of the legal rule governing predatory pricing. Immediately before the second stage, but after the first stage, a potential entrant decides whether to pay the sunk costs necessary to enter the market and begin competing. During the second stage, the entrant and incumbent monopoly both simultaneously choose prices (assuming that the potential entrant in fact decided to enter).

Both the entrant and the incumbent produce with constant marginal cost and no capacity constraints.

Define variables as follows:

$c_{\text {low }}=$ the marginal cost of the monopoly incumbent;

$p_{1}=$ the stage 1 equilibrium market price;

$p_{2}=$ the stage 2 equilibrium market price;

$s=$ the sunk investment necessary for the potential entrant to enter;

$c_{\text {high }}=$ the marginal cost of production for the entrant, $c_{\text {high }}>c_{\text {low }}$;

$D(p)=$ the demand in either stage as a function of the lowest price charged (all customers buy from the lowest priced producer);

$p_{\text {monop }}=$ the monopoly price that maximizes short run profits for the monopoly incumbent.

Consider the equilibrium under existing predatory pricing law. If the entrant decides to enter the market, it will be in Bertrand competition with the incumbent. ${ }^{60}$ The unique equilibrium has the stage 2 market price $p_{2}=c_{\text {high }}$, with all output produced by the incumbent. (At any price above $c_{\text {high }}$, both the incumbent and the entrant would have an incentive to undercut their rival's price and get all the demand. At the price $p_{2}=c_{\text {high }}$, if anyone were going to purchase from the entrant, the incumbent could offer a price slightly below $c_{h i g h}$ in order to attract that demand.)

In this equilibrium, the incumbent's low prices prevent the entrant from making sales now and in the future. Is this predation? The answer depends upon the meaning of the word "predation." In this case, the incumbent's price $p=c_{\text {high }}$ exceeds its cost, $c_{l o w}$, and therefore does not violate section 2 of the Sherman Act under Brooke Group. Since the price maximizes shortrun profits, it is not even predatory under the broader definitions of Bork and Ordover, which include short-run, non-profit-maximizing behavior that

59. As with any formal model, I consider a stylized situation that ignores many of the complications inherent in any specific setting but that has the advantage of allowing us to focus attention on general issues.

60. See generally DENNIS W. CARLton \& JefFrey M. PERLOFF, MODERn Industrial ORGANIZATION 272-76 (1990) (providing a background discussion of Bertrand competition). 
is only profit-maximizing because of deleterious effects on long-run competition. ${ }^{61}$ Nonetheless, this price cut is predation under the definition proposed in this Essay.

Whatever one calls this behavior, if it is allowed, it will discourage the potential entrant from entering, because if she does enter, she will lose her sunk investment. In equilibrium, we will never observe entry or predation. Entry, followed by the incumbent's reaction of driving the entrant from the market with above-cost pricing, would only occur if the entrant made a mistake.

Proposition: The unique equilibrium in this model involves the incumbent monopoly pricing at $p_{\text {monop }}$ during both stages and no entry occurring in stage 2.

Predation in this model (unlike the typical view) involves no short-term sacrifice. Since the predator's cost is below the entrant's at the margin, since the goods are homogeneous, and since competition is over prices, the incumbent's short-run maximizing response is to drive the entrant entirely from the market. In many settings, of course, some short-run sacrifices (even if not actually loss-causing) are required for predation. In such cases, more future periods would need to be added to the model to rationalize the behavior. The sacrifice would only be rational if the predator lessened competition in the future (i.e., by convincing the entrant and other would-be entrants of its toughness or its low costs). ${ }^{62}$ The lesson to draw from this model, though, is that incumbents with cost advantages may find predation rational and even short-run maximizing, even in a full information setting. ${ }^{63}$ Hence, it makes little sense for the law to focus exclusively on the failures of incumbents to short-run-maximize, or, indeed, on extreme failures that

61. See Int'l Air Indus. v. Am. Excelsior Co., 517 F.2d 714 (5th Cir. 1975) (finding an exception to the Areeda-Turner rule in which pricing above average variable cost can be illegal as predatory pricing if it is below the short-run profit-maximizing price and entry barriers are high enough to allow recoupment).

62. Kreps et al., supra note 56; Kreps \& Wilson, supra note 56; Milgrom \& Roberts, Limit Pricing, supra note 56; Milgrom \& Roberts, New Theories of Predatory Pricing, in INDUSTRIAL STRUCTURE IN THE NEW INDUSTRIAL ECONOMICS 112 (Giacomo Bonnano \& Dario Brandolini eds., 1990); Milgrom \& Roberts, Predation, supra note 56; Janusz A. Ordover \& Garth Saloner, Predation, Monopolization and Antitrust, in 1 HANDBOOK OF INDUSTRIAL ORGANIZATION 537 (Richard Schmalensee \& Robert D. Willig eds., 1989).

63. Contrast this result with the more traditional view of Joskow \& Klevorick, supra note 24, at 255 , which states that "no practical way exists to distinguish a predatory price cut to a point above average total cost from one that is a short-run profit-maximizing response to the growth of competition." If a predatory price cut is one that injures consumer welfare, then this model shows that this dichotomy-although standard in the predatory pricing literature-is a false one. It may be better policy to deny the incumbent a short-run profit-maximizing response to entry because such a response can be predatory and reduce consumer welfare. 
involve losing money and pricing below appropriate measures of cost, as required by Brooke Group. ${ }^{64}$

Current law and most of the scholarship about predatory pricing have focused on the tradeoff between encouraging low prices during the periods when the incumbent competes with the entrant and the risk that prices may rise in the future (an extended version of this Essay's model during stage 3 and thereafter). In contrast, this Essay suggests focusing attention ex ante instead of ex post. That is, it suggests focusing attention on encouraging entry and on encouraging low prices during stage 1.

The incumbent in the model has two cost advantages over the entrant. First, it has already sunk the expenditure, $s$. Second, the monopoly has lower variable costs. Only the first advantage is strictly required for the result to hold. The second advantage, however, makes the result more robust to relaxing other assumptions in the model. For example, the model assumes that marginal costs do not rise no matter how much the monopoly produces. If the monopoly has lower marginal costs than the entrant, then the results will still hold as long as the marginal costs of the monopoly do not rise too much. In particular, no matter how small $s$ is, the results will continue to hold as long as the monopoly's marginal cost when it produces $D\left(c_{\text {high }}\right)$ has not risen above the cost of the entrant, $c_{\text {high }}$. The larger the barrier to entry, $s$, the more the monopoly's marginal costs can rise along with increased output without attracting entry.

A monopoly will often enjoy noncost advantages as well. Its product, quality, and brand name may be familiar to customers, as in the case of NutraSweet compared to generic aspartame. ${ }^{65}$ It may offer valuable frequent flyer miles over a large network, as does American Airlines. Its product may be more valuable because of other demand-side network effects. ${ }^{66}$ Noncost advantages typically mean that a monopoly can outcompete an entrant at any given price. Hence, as with a cost advantage, entry may be pointless when the law only offers protection from below-cost predation.

The potential problem of indefinite high prices would not exist if the incumbent had several equal competitors who had already incurred the entry cost, $s$, and could produce at $c_{l o w}$. In that case, even without more entry

64. Even the proposed enforcement policy of the Department of Transportation under 49 U.S.C. $\$ 41712(1994)$, which was an attempt to state a nonpermissive predation rule for airline competition, continues to focus on nonmaximizing behavior as the trigger for liability. See Enforcement Policy Regarding Unfair Exclusionary Conduct in the Air Transportation Industry, 63 Fed. Reg. 17,919 (Apr. 10, 1998).

65. See the discussion of Holland Sweetener and NutraSweet in BARRY J. NALEBUfF \& ADAM M. BRANDENBURGER, CO-OPETITION 72-76 (1996).

66. For example, Microsoft Word is more valuable to most users at this point than WordPerfect, in part because it has a larger user base, which facilitates file exchange and collaboration, as well as formal and informal technical support. 
we would expect competitive prices to prevail as competition among firms drives the price down to $c_{\text {low }}$.

If the incumbent and competitors have capacity constraints, the price, $p$, would exceed $c_{\text {low }}$, and, in the long run, the margin $p-c_{\text {low }}$ would compensate firms for their investment in capacity. New firms would only enter if they had lower costs of capacity or if their costs of operation were below even $c_{\text {low }}$. Such entry could trigger a price war and lower prices toward, or to, $c_{\text {low }}$. Although charges of predation could arise during a price war, since an entrant will only be tempted to enter a competitive market when it has some cost advantage, the law does not need to provide the entrant any special protection.

\section{A COMPARISON OF PREDATORY PRICING SCENARIOS}

This Part puts forward a typology of predation cases. The goal is not to be exhaustive but to show variety and to suggest that a single rule - the Brooke Group rule-does not fit all cases well. Each case is categorized as "aggressive" or "defensive" according to whether the alleged predator is the first actor, or is the second actor and is acting responsively. ${ }^{67}$

Scenario \#1: Limit Pricing (Aggressive). In this scenario, a lowcost monopoly prices low in order to limit entry. High-cost rivals will decide not to enter and low-cost rivals will enter. ${ }^{68}$

Scenario \#2: Wal-Mart (Aggressive). A national chain like Wal-Mart opens a store in a new locality and charges prices much lower than those that previously prevailed. These prices drive the preexisting stores out of business.

Scenario \#3: Low-Cost Monopoly, or Monopoly with Other Advantages (Defensive). A monopoly charges high prices. Another firm, despite having higher costs or other disadvantages such as a less desirable product, nonetheless can earn substantial profits by undercutting these high prices, so it enters the market. After entry, the incumbent cuts prices below its rival's cost and drives the rival out of the market.

Alternatively, as in the model in Part III, the monopoly may enjoy its position indefinitely without disturbance until another firm

67. Defensive low pricing is much more likely to be anticompetitive because it may substitute for aggressive low pricing in the first place and will tend to discourage others from aggressive pricing in anticipation of the response.

68. The low price might be a signal to potential entrants that the incumbent firm has low costs, so prices are apt to be low after entry. Alternatively, in a full information context, the low price might be set below the costs of most entrants so that they would not even consider entering. The incumbent might worry if it set a high price that a later dramatic price drop in reaction to entry could trigger a predatory pricing suit. 
with advantages emerges. Disadvantaged firms may realize in advance that the high prices do not actually represent a competitive opportunity if the advantaged monopoly is free to react.

Scenario \#4: Same-Cost Monopoly Without Advantage (Defensive). A monopoly faces a challenge from an entrant that can produce a comparable product at similar or lower cost. The monopoly attempts to drive it from the market with below-cost prices. The entrant reduces its production to limit its losses, while the incumbent must produce high quantities to keep prices low, and so suffers large losses. Eventually, either the rival exits or the incumbent relents and accommodates the entrant by reducing output and letting price rise above cost.

Scenario \#5: Oligopoly Discipline (Defensive). Prices are relatively high and all firms are comfortable. One gets greedy and tries to capture more of the market with low prices or some innovation. Another firm, or the rest of the firms in concert, cuts prices in an effort to discipline its rival. Although they have little hope of driving the aggressor from the market, they do hope to chasten its aggressive behavior and return to the prior comfortable equilibrium.

A large fraction of the writing about predatory pricing seems concerned either explicitly or implicitly with the same-cost monopoly scenario. ${ }^{69}$ As discussed earlier, this literature argues that the predator will face much larger losses than its rival during the predation stage. In order to drive its rival from the market, the predator must drive prices below the rival's costs, and, if the rival has the same average cost as the monopoly, below the monopoly's average cost as well. Because the monopoly has a larger market share, its losses will be larger than those of the rival. The situation is made worse for the monopoly, however, because in order to drive prices down, the monopoly must increase industry output and supply anything that the market demands that other firms will not supply. Given the below-cost price that the monopoly seeks to maintain, the monopoly may wind up producing most or all of industry output. Hence, the monopoly's losses could far exceed those of its rival. Holding financing capabilities equal, the rival could continue to incur losses (without exit) for as long as, or even longer than, the incumbent. The rival will therefore not be quick to exit permanently (although, as suggested above, it may temporarily reduce output), because it will doubt that the predator will be willing to continue to bleed red ink. If the prey feels this way, then the predator in fact has no

69. For example, most of Easterbrook's analysis explicitly concerns the case where rivals are equally or more efficient than incumbents, yet his conclusions are stated for the general case. Easterbrook, supra note 3, at 272-76. 
reason to continue to incur losses. If the predatory period needs to be very long to drive the entrant from the market, a predatory strategy will be unprofitable to the incumbent. A rational incumbent will usually appreciate this fact and not attempt the predation.

Although not thoroughly compelling, this standard argument is reasonable for the same-cost monopoly scenario. ${ }^{70}$ When considering this scenario, then, two issues leap out. The first is that predatory pricing seems unlikely to be attempted and still less likely to succeed. Second, predatory pricing will not typically succeed in the same-cost scenario if the incumbent prices above cost (certainly not if it prices above average total cost), because the rival would have no reason to exit. ${ }^{71}$

A judge or scholar who reasons this way has several alternatives for dealing with the low-cost monopoly case. The first, and often most convincing, tactic is to ignore the possibility. Alternatively, she may assert that, in general, rivals will have access to similar production technologies and argue that antitrust policies should not be based on exceptional cases.

Another alternative is taken by Bork, who seems to embrace the possibility of a low-cost monopoly, but argues nonetheless that the predator's losses will be proportionally higher than its victim's. ${ }^{72}$ Since Bork's argument continues to be cited favorably in recent court decisions, ${ }^{73}$ it is worthwhile to point out its lack of generality. Although Bork asserts several times that "nothing [in this conclusion] depends on the exact numbers," ${ }^{74}$ in fact everything depends on the numbers he chooses. In his example, to drive out its rival, the predator must incur losses 11.2 times higher than its rival's losses. Under different cost assumptions in which the

70. Although this standard argument is reasonable, it is not thoroughly compelling in a repeated game. In principle, even if two firms have equal costs, almost any outcome is possible according to the "folk theorem." See DREW FuDENBERG \& JEAN TIROLE, GAME THEORY 150-60 (1993). The profits and output of one firm can be held arbitrarily low (even with prices still high) if it expects that increases in its output will be met with a dramatic price war. The question becomes whether such expectations are reasonable and likely.

71. An incumbent and smaller rivals or potential entrants might produce using the same technology, and so have identical cost functions, yet very different average costs. Because production is subject to increasing returns to scale, as more output is produced, average costs fall. In that case, the incumbent may price above its average total cost but below its rival's average cost. The rival might take a long time to increase its demand to levels that would yield costs as low as the incumbent monopoly. For this reason, the monopoly might be able to engage successfully in predation with above-cost pricing. This situation is best understood as one where increasing returns lead to asymmetric costs (the low-cost monopoly scenario). The lower costs of the monopoly arise because the incumbent is well-established. In much the same way, the Stackelberg leader in Spector's model can be viewed as having lower costs that derive from a combination of increasing retums and its leadership role. See SPECTOR, supra note 6. Again, the possibility of above-cost predation can be seen as arising from cost asymmetries.

72. See BORK, supra note 25 , at 149-54.

73. E.g., Rebel Oil Co. v. Atl. Richfield Co., 51 F.3d 1421 (9th Cir. 1995).

74. BORK, supra note 25 , at 151. 
monopoly has larger cost advantages, but with the same competitive price, the predator need incur no losses at all to drive its rival out of the market. ${ }^{75}$

As the model in Part III makes clear, above-cost predatory pricing is quite possible if rivals have higher costs than the incumbent monopoly (where predatory pricing means low prices that hurt consumers by limiting competition).

Scenario \#3 is probably substantially more common than Scenario \#4. After all, a firm rarely achieves monopoly without one or more advantages. Any such firm probably has gone down the cost learning curve and produces more efficiently than a newcomer. The industry may enjoy increasing returns to scale or scope. The firm may simply have a firstmover advantage and be able to hide behind entry barriers from start-up costs. It may have figured out how to make a superior quality product, enjoy demand-side network externalities, or simply have a familiar and trustworthy brand like NutraSweet. Some advantage, or combination of advantages, gives the firm monopoly power in the first place.

The very advantages that give a firm monopoly power can allow it to drive out rivals without pricing below cost. Consider, for example, Barry Wright.$^{76}$ Pacific was the only domestic maker of mechanical snubbers for nuclear power plants in the United States. Foreign manufacturers could not sell in the United States, and hydraulic snubbers were a poor substitute.

75. Bork constructs an apparently convincing diagrammatic and numerical example to prove his point. In his example, before the predation, the monopoly and its rival both sell at a price of $\$ 40$, with the monopoly supplying 8000 units and its victim supplying 2000 units. In order to drive the rival from the market, Bork assumes that the predatory monopoly cuts its price to $\$ 20$, $\$ 10$ per unit below the victim's minimum average variable cost of $\$ 30$, and that the victim reduces its output to 1000 units per week at an average variable cost of $\$ 30$ per unit in order to limit its losses. Because of the price fall, demand increases to 12,500 units per week, so the monopoly must increase output to 11,500 units per week. As Bork draws the diagram, at this output, the monopoly has average variable costs of $\$ 39.50$, implying that it fails to recover $\$ 224,250$ of its variable costs. The predator's losses per week exceed the victim's by a ratio of 22.4 to 1 , or 11.2 to 1 after Bork accounts for fixed costs. Id. at 151-52.

Despite Bork's assurances that the exact numbers do not matter, the numbers do matter, which makes this example more rhetoric than argument. Bork draws cost curves that assume that the incumbent monopoly firm has a cost advantage, but this advantage disappears when the predator produces a lot and the victim produces very little. This factor becomes relevant because the monopoly must increase production to effect its predator strategy. If we drew a slightly different cost curve for the monopoly in Bork's example, our conclusions about losses would be quite different. Suppose, for example, that the monopoly has a marginal cost of $\$ 5$ per unit for all units less than 6000 , and $\$ 40$ per unit for all units produced in excess of 6000 . Suppose also that the predator charges $\$ 25$ per unit, where demand is 11,000 units. Now if the victim stays in the market as Bork suggests, producing 1000 units, instead of the predator suffering losses far in excess of the victim, the predator will have revenues of $\$ 250,000(10,000$ units multiplied by $\$ 25$ per unit), exceeding its variable costs of $\$ 190,000$ by $\$ 60,000$. Since the victim of the predatory pricing is suffering losses, and it knows that the predator is not, it may exit quickly. Hence, if the predator has the cost advantage I suggest, then far from being implausible, the predatory strategy seems likely to be successful. Bork is only able to conclude that predation is implausible because he gives the predator a steeply increasing marginal cost curve, so that it has huge losses from the predation.

76. Barry Wright Corp. v. ITT Grinnell Corp., 724 F.2d 227 (1st Cir. 1983). 
Barry Wright's costs would be much higher if it were able to make snubbers at all, so Pacific's price cut was able to keep Barry Wright out of the market even though Pacific's price remained above every measure of its own cost. If the case did not fit into Scenario \#3, it was only because Pacific's price cut may have been before it was aware of Barry Wright's entry plan, so that the case may have been closer to the limit pricing of Scenario \#1. Judge Breyer expressed concern in Barry Wright that if abovecost prices like Pacific's could be predatory and hence illegal, such a rule would likewise ban limit pricing (Scenario \#1) because limit prices also exclude rivals by deterring their entry. That concern would have been addressed, however, if Breyer had ruled against Barry Wright on the ground that Pacific lowered its prices before knowing of Barry Wright's entry instead of on the ground that Pacific's price exceeded its own cost. It is the timing of the price cut that separates Scenario \#1 from Scenarios \#3 and \#4.

Similarly, timing separates Scenario \#2 from Scenarios \#3 and \#4. In the Wal-Mart scenario, the plaintiff is already in the market when the entrant is accused of predatory pricing. As in the limit-pricing scenario, the alleged predator is behaving aggressively. Ironically, for exactly this reason, a rule of per se legality would be best. The behavior constitutes aggressive competition, and the Chicago School analysis applies. Customers gain, at least in the short run, from allowing the newcomer to price aggressively, even when it drives competitors from the market. If the newcomer achieves market dominance (monopoly power), this does not hurt consumers, so long as it continues aggressive pricing (now limit pricing) in order to maintain its position. If instead the firm prices high and relies upon the threat of pricing low after entry to deter entry, we have moved to Scenario \#3, which this Essay argues should be the focus of predatory pricing doctrine.

Scenario \#5 could in principle present a problem for competition similar to the one in Scenario \#3. As with Scenario \#3, the defensive reaction may chill the first competitive price cut (by the maverick in this case, and by the entrant in Scenario \#3). Scenario \#5 is essentially Brooke Group, and many of the points the Court made in that case distinguish it from the low-cost monopoly case, ultimately justifying the cautious and noninterfering approach that the Court took in Brooke Group. First, when there are many firms of comparable size in an industry, it seems less likely that one would have such peculiar advantages that it could drive another from the market without pricing below its own cost. Accordingly, the costbased test in Brooke Group seems sensible even in light of the arguments put forward in this Essay, and the Chicago School arguments apply. Recouping the losses incurred during the predation period would be risky at best, as it would require coordinated supracompetitive pricing by several firms. Moreover, if one firm incurred most of the losses, as Brown and 
Williamson allegedly did in Brooke Group, it would have to recover those losses through high prices in only its fraction of the market.

\section{A New CATEgory of PRedatory Pricing}

The critique thus far suggests the need for a new definition of predatory pricing under section 2 of the Sherman Act. The purpose here is not to shut down the existing avenue of proving predatory pricing (i.e., showing below-cost pricing and the possibility of recoupment), but rather to create a new one. I first discuss monopolization and then examine attempted monopolization.

\section{A. Monopolization}

A good starting point is the often-quoted Grinnell formulation of monopolization under section 2: the "willful acquisition or maintenance of [monopoly power] as distinguished from growth or development as a consequence of a superior product, business acumen, or historical accident." 77 This is the basic formulation of monopolization that descends from Learned Hand's decision in Alcoa that requires some exclusionary behavior on the part of a monopoly before section 2 is triggered. As discussed in Part II, monopoly status alone is insufficient for a violation. ${ }^{78}$

Pricing below rivals' costs, from the moment they enter until the time they exit, certainly seems more "willful maintenance of monopoly power" than "historical accident" and should be illegal under Grinnell. True, this strategy would only be effective for a low-cost monopoly or a monopoly with particularly good products. However, if we consider the reason behind the superior product exception, we will see that this exception does not apply to strategic behavior.

Monopolies based on superior products or low cost paired with low prices are legal because consumers benefit. If, however, these advantages are not used for limit pricing as in Scenario \#1 but are instead used to deter entry and to retake a market after entry, then consumers do not benefit and the monopoly should not be able to use its superiority as a shield against a monopolization charge. A monopoly will always have to be superior in some respects to keep its monopoly, but this does not make its actions per

77. United States v. Grinnell Corp., 384 U.S. 563, 570-71 (1966).

78. Learned Hand is less than transparent about the particular act by Alcoa that was exclusionary. His clearest assertion is that Alcoa doubled and redoubled its production or capacity, precluding successful entry. United States v. Aluminum Co. of Am., 148 F.2d 416, 431 (2d Cir. 1945). 
se legal. ${ }^{79}$ Attaining or preserving a monopoly by charging prices lower than other firms' costs generally benefits consumers and is procompetitive ${ }^{80}$ On the other hand, a firm that preserves its monopoly by charging low prices only when its rivals make the mistake of entering the market, and only until they exit, denies consumers the benefits from competition on the merits. Firms that could provide at prices below the monopoly's going price do not enter, because they do not think the price will stay at pre-entry levels after they enter. Customers are denied the benefits they might get in the absence of the monopoly firm because most of the time they must pay more than they would if the products were provided by others. Note how different this situation is from the limit pricing scenario or the antitrust teacher's illustration where a monopoly with low cost prices slightly below its rivals' costs to discourage their entry. In that case competition on the merits is not denied; the costs of rivals are simply too high for them to attract customers.

These arguments motivate the following new category of predatory pricing:

Proposed Category of Predation: Monopolization under Sherman Act section 2 includes price reductions or quality improvements by an incumbent monopoly in response to a substantial entry before the entrant has had a reasonable time to recover its entry costs and become viable. Essentially, this new category of predatory pricing mandates a price freeze for an incumbent monopoly, where the freeze is triggered by a substantial entry.

The general logic behind this idea is suggested by the critique in Part II. If an incumbent monopoly can and will quickly reduce prices below an entrant's cost so that the entrant cannot recover the cost of entry, then potential entrants with costs above the incumbent's will not enter. Since this pricing strategy allows a low-cost monopoly to maintain its monopoly to the detriment of consumers, it should constitute monopolization and violate section 2 . Below, I briefly refine various aspects of the definition.

79. United Shoe's customers would likely not have agreed to such a wide variety of contractual restrictions if United Shoe's machinery had not been superior, as Judge Wyzanski granted. Furthermore, Wyzanski was convinced that these restrictions supported United Shoe's monopoly. Hence, in a strong sense United Shoe owed its monopoly to its superior products. This fact was no defense because consumers were not benefiting, or at least not benefiting as much as they would have, had United Shoe been denied these strategic contracts. United States v. United Shoe Mach. Corp., 110 F. Supp. 295, 344-46 (D. Mass. 1953), aff'd per curiam, 347 U.S. 521 (1954).

80. Here, I adopt Bork's definition of competition: “'Competition' for purposes of antitrust analysis must be understood as a term of art signifying any state of affairs in which consumer welfare cannot be increased by judicial decree." BORK, supra note 25, at 51. In this Essay, however, consumer welfare is interpreted in the traditional way, as consumer surplus rather than producer plus consumer surplus. 
Substantial entry. The reason to limit the protection to a "substantial" entry is to encourage entrants to enter with gusto at low prices and high capacities. In short, the requirement is to ensure that the entrant brings consumers substantial benefits. Hence, a firm should qualify as a substantial entrant only if it prices substantially below the incumbent and has the capacity or the prospect of supplying a substantial portion of the market. Without this limitation consumers might get little benefit from the entry that this stringent predatory pricing rule protects because an entrant might price only slightly below the incumbent.

Price reductions of twenty percent or more should automatically qualify as substantial, provided that the entrant is not unduly limited in capacity. ${ }^{81}$ Entry might be held to be insubstantial if the capacity of the entrant is severely limited and the entrant cannot supply a substantial portion of the demand at its low prices. If courts sought to maximize total wealth (the sum of producer and consumer surplus), they might require that an entrant show not only that its prices were low, but also that its costs were low enough that its entry improved overall welfare. This Essay presumes, though, that antitrust's principal goal is to maximize consumer welfare.

Might price reductions of less than twenty percent qualify as substantial? In some markets they should, and it would be reasonable to decide substantiality on a case-by-case basis. One advantage of a bright-line rule is that it would let incumbents know where they stand. Monopolies that price only slightly above their average cost would be insulated from the entry of higher-cost entrants if they could credibly convey a willingness to price below the entrants' cost after entry, as illustrated in Part III. However, these monopolies do consumers little harm and may enhance market efficiency.

Monopoly incumbent. The new category applies only to monopoly incumbents and envisions no new test of monopoly beyond those ordinarily administered under section 2 . Since this new definition of predatory pricing is motivated by the likely possibility that a monopoly incumbent has a variety of advantages over entrants, it might seem reasonable to limit the

81. The figure twenty percent is intended to balance the desire to encourage entry with the desire that an entrant provide substantial benefits to consumers before it is protected. Naturally, the exact figure involves some guesswork. The reader may wonder whether courts can create such numerical thresholds, or whether that would require a legislative act. There is precedent for introducing arbitrary but not unreasonable numerical thresholds without legislation in other areas of antitrust. See, e.g., United States v. Phila. Nat'l Bank, 374 U.S. 321 (1963) (holding that mergers leading to a greater than thirty percent market share create a presumption of substantial lessening of competition); 1992 Horizontal Merger Guidelines, 57 Fed. Reg. 41,552 (Sept. 10, 1992) (creating a variety of arbitrary numerical thresholds jointly promulgated by the FTC and the DOJ, which have been very influential with courts); CARL KAYSEN \& DONALD F. TURNER, ANTITRUST POLICY (1959) (suggesting that twenty percent market share should be the line of prima facie unlawfulness for mergers); George J. Stigler, Mergers and Preventive Antitrust Policy, 104 U. PA. L. REV. 176, 182 (1955) (suggesting that shares exceeding twenty percent after a merger be presumptively unlawful). 
definition to "incumbent monopolies with substantial proven advantages." Two considerations mitigate against doing so. First, if an incumbent monopoly genuinely has no cost or other advantage, the monopoly may be contestable and the monopoly may price close to a competitive level anyway, because entrants would be perched waiting in the wings. ${ }^{82}$ In that case, no entrant could price low enough to trigger the price freeze. Second, proving monopoly power already entails showing that a firm can profitably raise prices above the competitive level. This generally requires a showing or inference of substantial advantage, whether implicitly or explicitly. ${ }^{83}$

Potential advantages that create monopoly are many. The monopoly may have lower costs than rivals due to an innovation or superior organization. ${ }^{84}$ The monopoly may enjoy increasing returns to scale or scope, as American Airlines surely does at its hub in the Dallas-Fort Worth airport. Experience in an industry is almost always an advantage and tends to lower costs substantially (through learning-by-doing). Another advantage for a monopoly is that it has already sunk whatever expenditures are necessary to enter the industry. ${ }^{85} \mathrm{~A}$ monopoly may also enjoy demand advantages owing to the familiarity of its products or network externalities. ${ }^{86}$

Duration of the price freeze. How long must the monopoly abstain from price reductions under this definition before the reduction ceases to be predatory? One limit is implicit in the definition: only so long as the

82. See generally William J. Baumol et al., Contestable Markets and the Theory OF INDUSTRY STRUCTURE (1982) (giving assumptions under which the threat of hit-and-run entry forces incumbents to price low).

83. This "showing" is often not direct in practice. As Areeda and Kaplow note, "most judicial pronouncements on the proof of monopoly power embody little more than a vague perception that a very large market share sufficiently approximates total control to be fairly regarded as a monopoly." PHILlIP AREEDA \& LOUIS KAPLOW, ANTITRUST ANALYSIS 574 (5th ed. 1997). The idea that a seventy percent or more market share would create a good prima facie casc of significant advantages and power over price is plausible. The elasticity of a firm's demand, i.e., price sensitivity, is typically much smaller for a firm with high market share than for one with low market share. A firm's elasticity of demand equals the ratio of the percentage change in quantity demanded to the percentage change in price. See DENNIS W. CARLTON \& JEFFREY M. PERLOFF, MODERN INDUSTRIAL ORGANIZATION $98 \mathrm{n} .7$ (2d ed. 1994). A firm with a $70 \%$ market share that cuts its output by $10 \%$ cuts market output by $7 \%$, ignoring the possibility of other firms increasing their output. If the market demand elasticity is 1 , price will rise by $7 \%$. In contrast, a firm with only a $5 \%$ market share could only raise price by $5 \%$ even if it stopped producing entirely.

84. Some would argue that asymmetric costs, at lcast at the margin, are the only explanation for why a firm with an eighty percent market share and a firm with a twenty percent market share in the same market can both simultaneously decide not to increase output. Given the likely difference in firm-specific demand elasticities for the same market demand, one should expect a firm with high market share to have substantially lower incremental costs than a firm with low market share. See, e.g., Joseph Farrell \& Carl Shapiro, Optimal Contracts with Lock-In, 79 AM. ECON. REv. 51 (1989).

85. A famous economic maxim is that sunk costs do not matter. If a firm decides to enter, it is true that its sunk costs of entry will not matter thenceforth. But, if a firm will not recover these costs, then they will affect its decision before entry and prevent it from sinking them.

86. See the discussion in Joskow \& Klevorick, supra note 24, at 228-29. 
monopoly is a monopoly. Once the rival entrant has made sufficient inroads that the incumbent firm is no longer a monopoly, the incumbent is free to compete.

Duration should also be guided by the rule's goal, to give entrants an incentive to enter and allow consumers to enjoy the fruits of competition. The standard "sufficient time to recover its entry costs and become viable" might reasonably be replaced by a rule of twelve to eighteen months, with exceptions for unusual industries judged under the old standard. If the entrant does not supply all the demand at its low prices, this reason might justify a partial removal of the price freeze, at least so that the incumbent could lower price enough to fill unserved demand. (This exception would not allow American to cut prices, increase flight frequency, and leave Vanguard's seats empty, as it allegedly did.)

Administrative ease. One potential advantage of this new supplemental definition of predation over existing ones is administrative ease. Comparing prices to cost has proven very difficult for courts. ${ }^{87}$

Liability under this Essay's definition of predatory pricing is easier to judge. If an entrant charges a price substantially below the incumbent's price (I suggest twenty percent or more), this would generally trigger a price freeze for the incumbent. Prices are more easily and reliably measured than cost. If the incumbent charges a wide range of prices as airlines do, the application of the rule is somewhat more complex, but not inordinately so. The price freeze would translate into a rough freeze on average price, where that average is weighted by sales.

The administrative ease advantage is bound to disappear somewhat in practice, because courts will no doubt find it necessary to make allowances for changes in cost, at least for dramatic changes in cost. For example, if fuel prices fell by fifty percent, and Vanguard, in reaction to this drop, entered the Dallas market at steep discounts before American had had time to cut prices, courts might wish to allow American the chance to respond. Likewise, if fuel costs fell after Vanguard's entry, most courts would be inclined to allow American to lower its price in reaction to its cost reductions, even if it could not in response to Vanguard's entry.

If antitrust were concerned solely with fairness to the monopoly, both allowances should be made for cost reductions, at least when the reductions are dramatic. But with consumer welfare as the goal, the case is less clear. If courts insisted upon a price freeze even though costs fell before entry, this would only encourage firms attempting the limit pricing strategy to remain vigilant in keeping prices low. Such a reaction would benefit

87. Areeda, who proposed this idea in Areeda \& Tumer, supra note 20, later conceded that it is notoriously difficult in application. Joseph F. Brodley, Proof of Efficiencies in Mergers and Joint Ventures, 64 ANTTTRUST L.J. 575, 609 n.98 (1996) (citing 3 PHILIP AREEDA \& HERBERT HOVENKAMP, ANTITRUST LAW \& 715.2a (Supp. 1995)). 
consumers. The situation in which costs fall unexpectedly after entry is murkier.

Regardless of whether falling costs are allowed as a defense to accusations of predatory pricing, no great point of principle is lost if the judgment is fairly rough and ready, unlike the price-less-than-cost judgment in existing cases, which requires a fairly precise measure of cost. If costs fell by a small amount, say roughly 5\%, American Airlines might be justified in lowering prices somewhat but should be forbidden from cutting fares 25\% to match Vanguard. If American's costs fell by 5\% and they "got away" with a $10 \%$ price reduction, this would be no disaster; Vanguard would still have a substantial price advantage and good entry incentives. An administratively simple and acceptable solution would be to disallow any American price reduction unless it showed costs fell dramatically, where "dramatically" meant an amount equal to or greater than the VanguardAmerican price difference, which must be at least $20 \%$ to trigger the rule at all. Cost reductions this large are rare over short periods of time. With such a rule there would be little fear of endless courtroom squabbles over cost.

\section{B. Attempted Monopolization}

Should the rule proposed here apply in attempted monopoly cases, as well as monopolization cases? Attempted monopolization requires showing (1) the specific intent to monopolize a market and (2) an exclusionary act that (3) creates a dangerous probability of successfully achieving monopoly power. ${ }^{88}$

To explore how the logic in this Essay should apply to attempted monopolization, consider a firm with a large enough share of the market that monopolization is a plausible threat, but with too many competitors capable of expanding their output for the firm to be deemed to have monopoly power. For concreteness, imagine the firm has a $40-60 \%$ market share, and suppose that the rest of the market is split among firms with 10$15 \%$ or less of the market. What keeps the smaller firms from expanding their output? Most likely, one or both of two possibilities applies. First, these firms may have higher marginal costs than the dominant firm and so charge prices close to their marginal costs of production, making an output expansion unprofitable. Second, these firms may not lower price and expand output because they expect such efforts would be greeted with a proportional (and therefore much larger) output expansion of the dominant firm, together with a price cut, making the small firm's price drop unprofitable. (Worse yet from the vantage of the small firm, the large firm's response could be disproportionate.) The full answer is probably a mixture

88. See Spectrum Sports v. McQuillan, 506 U.S. 447 (1993). 
of the two possibilities. If the competitors' prices are only moderately higher than the dominant firm's, then in a homogeneous goods market we could only explain their low output by the threat of a substantial reaction by the dominant firm should they expand output and lower price. ${ }^{89}$

The question for this Essay is whether the price reaction of the dominant firm is predatory and anticompetitive only if it prices below its own cost, or whether it could be viewed as an exclusionary predatory act under section 2 of the Sherman Act if it is above cost. Certainly just such a reaction will discourage smaller firms from pricing more aggressively (if their own costs allow) and picking up market share. The reaction therefore discourages the initial price cut, just as it discourages entry in the monopoly case. If the other elements of attempted monopolization are satisfied, there is no evident reason to remove section 2 liability simply because the firm prices above its cost.

\section{The Meeting-Competition Defense}

The district court in American Airlines raised an interesting objection to the Department of Justice's arguments that is relevant to this Essay's proposal. Judge Marten argued that an accused predator could always defend itself from section 2 liability on the ground that it only met the competitor's price and did not beat it. Marten claimed that this meetingcompetition defense is "predicated on" the explicit meeting-competition defense under the Robinson-Patman Act. ${ }^{90}$

Elsewhere, I have argued that the meeting-competition defense should not apply even under the Robinson-Patman Act when meeting competition is the very act that the plaintiff claims leads to anticompetitive effects. ${ }^{91}$ In such a case, it makes little sense to point out that the monopoly only met the entrant's prices, and that this must therefore be procompetitive. Only if the prima facie case is premised on something other than price matching would pointing to price matching in rebuttal make sense.

Originally, Standard Oil provided the foundation for the purported absolute defense of meeting competition under the Robinson-Patman Act. In that case, the Court reasoned that the meeting-competition argument

89. Observe that if there is no threat of the dominant firm reacting with increased output, the price elasticity of demand for a firm with a ten percent market share will typically be five times that of a firm with fifty percent market share. Since the markup of a profit-maximizing firm (i.e., (price - cost)/price) equals the inverse of the elasticity, if there is no threat of reaction, then the markup of the dominant firm would need to be five times as high as that of the small firm $(p-c) / p$, which would indicate that the large firm has dramatically lower costs than the small firm instead of moderately lower costs.

90. 15 U.S.C. $\$ 13($ b) (1994).

91. Edlin, supra note 22, at 563-65. 
made by the plaintiff was logically flawed. ${ }^{92}$ In other words, meeting competition was not a substantive right on its own that trumped anticompetitive effects. Instead, it provided compelling evidence that there were no anticompetitive effects. The Court imagined that meeting competition would always constitute compelling proof of the lack of anticompetitive effects.

In the context of above-cost predation, the fact that the monopoly's price cut only met the entrant's price does not prove that this conduct produced no anticompetitive effects. The price cut could still make entry unprofitable even if it only met the entrant's price. First, at equal prices most customers may choose to remain with the incumbent, because, for example, it has an established record of quality, better name recognition, or a more valuable frequent-flyer program. Even if business splits evenly at equal prices, the entrant may lose money: The price could be profitable for the entrant at high output, but not when the entrant must split the market and cover its overhead from a smaller customer base.

Hence, even the threat that the incumbent will "meet the competition" may be sufficient to cause firms not to enter a monopoly market. In addition, if the incumbent cannot legally match an entrant's price after entry, it will need to price lower before entry. According to the logic put forth in this Essay, the ability to match prices may be the source of the anticompetitive problem. It would make little sense, therefore, to shield the incumbent from a section 2 attack via a "meeting competition" defense. Because courts have long interpreted the Standard Oil case to create an absolute defense of meeting the competition under the Robinson-Patman Act, it may be too late to distinguish cases where meeting competition is part of the prima facie case (i.e., part of the chain of arguments of anticompetitive effects) from cases where it constitutes a logical rebuttal of the prima facie case. However, no absolute meeting-competition defense should be extended to section 2 of the Sherman Act.

To extend an absolute meeting-competition defense to section 2 of the Sherman Act would perpetuate a substantial misunderstanding by the courts. Courts generally see defensive acts as procompetitive and aggressive acts as anticompetitive. Hence, a firm that suddenly cuts prices below all its rivals' tends to be seen as predatory. Those who respond by matching the price cut are seen as competitive. The truth, however, is generally the reverse. In industries that lack strong competition and have few firms-the industries where antitrust matters - the critical ingredient for competition is providing sufficient incentives for some firm-any firm-to lower price. Where competition is lacking we need strong incentives to create the first procompetitive act. Reactions by other firms

92. Standard Oil Co. v. FTC, 340 U.S. 231, 246-51 (1951). 
only serve to diminish these incentives. ${ }^{93}$ Hence, this Essay focuses on getting the incumbent to price low in the first place, or getting an entrant who prices low. Allowing a speedy reaction by incumbent firms produces less benefit than the first competitive act-and very likely involves a net cost, if we take into account its consequence on deterring initial procompetitive acts (i.e., entry).

\section{A Price Freeze Encourages Entry and Low Stage 1 Pricing}

\section{A. The Case of Known Entrant Costs}

Here I show that if a monopoly cannot react to a substantial entry, then entry will be more likely, holding constant the monopoly's behavior before the entry in stage 1 . In turn, the monopoly will have strong incentives to price low during stage 1 in order to deter entry. In short, the new category of predatory pricing creates two major ex ante advantages for consumers by making the market more contestable.

Consider the model in Part III, and assume that $p_{\text {monap }}>1.25 c_{\text {low }}$, such that a sufficiently low-cost entrant could profitably enter at a twenty percent discount and trigger the price freeze for the incumbent. In this Section, I assume that the monopoly knows the entrant's costs. An entrant must be able to charge a sufficiently high price during the second stage to cover its sunk cost, $s$. Assuming, optimistically, that the entrant captures the entire market, the break-even price $b$ for the entrant is the minimum price at which it can sell to the whole market and still recover the sunk cost $s$. This price solves the break-even equation:

$$
D(b)\left(b-c_{\text {high }}\right)=s .
$$

If the entrant can charge a price $p>b$ and be protected by the price freeze, then, it will find entry profitable.

Consumers should benefit under the proposed alternative predation rule. Possibility 1 is that the incumbent monopoly invests in entry deterrence. The incumbent monopoly could purchase full deterrence by pricing sufficiently low during stage 1 . Possibility 2 is that the incumbent monopoly decides not to invest in entry deterrence and instead maximizes short-run profits. In this event, the monopoly charges $p_{\text {monop }}$ during stage 1 . Consumers gain in stage 2 because if an entrant arrives on the scene, it will decide to enter under the proposed rule and charge a sufficiently low price to trigger the price freeze for the incumbent. Hence, under the twenty

93. United States v. Container Corp. of America, 393 U.S. 333 (1969), stands out for recognizing that a reaction of meeting-the-competition can be anticompetitive. 
percent discount interpretation of significant entry, the entrant will charge $0.8 p_{\text {manop }}$. (Technically, the entrant might charge an even lower price if its profit function were not single-peaked.)

\section{Possibility \#1: Limit Pricing}

The incumbent may find it profitable to deter entry by charging a stage 1 limit price $p_{\text {limit }}$ such that

$$
p_{\text {limit }} \leq 1.25 b \text {. }
$$

Given this low price, the entrant cannot charge the break-even price $b$ and still trigger the price freeze so that she is protected. If she tried to charge a price above $b$, there would be no price freeze, and her price would be undercut in the ensuing Bertrand competition. If she charged a price low enough to trigger the price freeze, she wouldn't recover her sunk cost, $s$. Hence any price less than $1.25 b$ is a limit price.

In this scenario, the alternative predation rule yields the benefit that the incumbent charges a limit price of $p_{\text {timit }}$ as long as the incumbent is threatened with entry. ${ }^{94}$ Provided that the entrant has sufficiently low costs (i.e., $c_{h i g h}$ and $s$ are sufficiently low), then this limit price will be less than the monopoly price $p_{\text {monop }}$ and typically will equal $1.25 b$.

Consumers will therefore benefit from the proposed predation rule, and social welfare will rise as consumers buy more at the low price and output expands. If the entrant's costs are too high, the proposed rule yields no benefits.

\section{Possibility \#2: Entry}

The second possibility is that the monopoly chooses the stage 1 price to exceed $1.25 b$. If $p_{l}>1.25 b$, entry will occur, and the incumbent will only profit during stage 1 . As long as the incumbent deters no entry, she might as well charge the monopoly price $p_{\text {monop }}$. The high price, together with the proposed predatory pricing rule, will lead to entry during stage 2 . The entrant can choose its most profitable price between $b$ and $0.8 p_{\text {monop }}$ and still be protected by the price freeze. The current predatory pricing rule, in contrast, does not facilitate entry because the entrant could be driven from the market with above-cost pricing without creating a valid predatory pricing claim.

94. In practice, limit pricing might not accur only during stage 1 . If we leave the two-stage case, then limit pricing, and its attendant benefits, might continue forever. 
Consumers benefit from the entry because they can buy at a price between $b$ and $0.8 p_{\text {manp. }}$. Although consumer surplus increases, producer surplus decreases. The effect on overall social welfare is ambiguous because production is now done by the high-cost entrant instead of by the incumbent. Still, the entrants' costs cannot be too high, because $b<$ $0.8 p_{\text {monop }}$. As I have argued, to the extent that the goal of antitrust is competition and low prices, the proposed predation rule has served the purpose, even if overall social welfare may have fallen. Moreover, if we extended the analysis to later stages when the incumbent is allowed to begin vigorous competition again, we would expect price to be driven down farther to $p=c_{\text {high }}$, or, if the entrants learned the "secret" of the incumbent's low costs, even to $p=c_{\text {low }}{ }^{95}$

The consumer gains from entry and competition would be impossible to attain were it not for the protection afforded by the price freeze under the proposed predation rule.

\section{Comparison of Possibilities \#1 and \#2}

Suppose that entrant costs are high, so that the break-even price $b$ is high. Limit pricing will then be attractive, because very little short-run profit needs to be sacrificed to prevent entry and preserve stage 2 profits. On the other hand, as costs fall and as the break-even price $b$ falls, possibility \#2 will be increasingly attractive to the incumbent monopoly. Even for very low-cost entrants, however, the monopoly may still opt for limit pricing. Consider the extreme case, for example, where the incumbent monopoly has no advantage and $b=c_{l b w}$.

Let $q$ be the probability that a potential entrant appears during stage 2, let $\pi_{\text {limit }}=D\left(p_{\text {limit }}\right)\left(p_{\text {limit }}-c_{\text {low }}\right)$ denote the profits from charging the limit price, and let $\pi_{\text {monop }}=D\left(p_{\text {monop }}\right)\left(p_{\text {monop }}-c_{\text {low }}\right)$ denote the profits from charging the

95. "Learning by doing" is common in many industries, so it is quite possible that after the entrant produces for a little while, its costs will fall to $c_{\text {low. }}$ See THOMAS R. GULLEDGE \& NORMAN K. WOMER, THE ECONOMICS OF MADE-TO-ORDER PRODUCTION (1986); Armen Alchian, Reliability of Progress Curves in Airframe Production, 31 ECONOMETRICA 679 (1963); Kenneth J. Arrow, The Economic Implications of Learning by Doing, 29 REV. ECON. STUD. 155 (1962); Partha Dasgupta \& Joseph Stiglitz, Learning-by-Doing, Market Structure and Industrial and Trade Policies, 40 OXFORD ECON. PAPERS 246 (1988); M. Thérèse Flaherty, Industry Structure and Cost-Reducing Investment, 48 ECONOMETRICA 1187 (1980); Drew Fudenberg \& Jean Tirole, Learning-by-Doing and Market Performance, 14 BELL J. ECON. 522 (1983); Pankaj Ghemawat \& A. Michael Spence, Learning Curve Spillovers and Market Performance, 100 Q.J. ECON. 839 (1985); Douglas A. Irwin \& Peter J. Klenow, Learning by Doing Spillovers in the Semiconductor Industry, 102 J. POL. ECON. 1201 (1994); Paul L. Joskow \& Nancy L. Rose, The Effects of Technological Change, Experience, and Environmental Regulation on the Construction Cost of Coal-Burning Generating Units, 16 RAND J. ECON. 1 (1985); Marvin B. Lieberman, The Learning Curve and Pricing in the Chemical Processing Industries, 15 RAND J. ECON. 213 (1984); William W. Nye, Firm Specific Learning-by-Doing in Semiconductor Production: Some Evidence from the 1986 Trade Agreement, 11 REV. INDUS. ORG. 383 (1996). 
monopoly price. Then, under limit pricing, the incumbent earns $\pi_{\text {linit }}$ during the period of limit pricing (stage 1) and $f \pi_{\text {monop }}$ during stage 2 , where $f<1$ represents the discount factor used to discount future returns and yield present value. ${ }^{96}$ In contrast, if it opts for short-run profit maximization, the incumbent will earn $\pi_{\text {попор }}$ from stage 1 and $f(1-q) \pi_{\text {толо }}$ from stage 2 , where $1-q$ is the probability that the incumbent is lucky and no entrant materializes. The decision to practice limit pricing can be thought of as a period of investment yielding later return, much as predatory pricing is normally conceptualized. The firm invests

$$
\pi_{\text {monop }}-\pi_{\text {limit }}
$$

by forgoing short run profits, and realizes

$$
f \pi_{\text {monop }}-f(1-q) \pi_{\text {monop }}=f q \pi_{\text {monop }}
$$

from higher expected stage 2 profits. Comparing the investment with its return, we see that limit pricing is the best course if

$$
(1-f q) \pi_{\text {monop }}<\pi_{\text {limit }}
$$

If demand is price-insensitive, so that $\pi_{\text {monop }}$ is very high, and the monopoly price far exceeds the limit price, then possibility \#2 will seem more attractive. Likewise, if the probability that a potential entrant materializes, $q$, is sufficiently low, or the firm is quite impatient, so that $f$ is low, then short-run profit maximization, i.e., possibility \#2, will be attractive. Otherwise, limit pricing will seem more attractive.

Hence, the new category of predatory pricing gives consumers one of two ex ante benefits in this case: (1) limit pricing or (2) entry and low stage 2 pricing. In general, as we shall see, consumers should enjoy some of each benefit.

96. The value today of a future payoff is called the present discounted value of that payoff. Since many economic problems require comparing amounts of money at different points in time, it is necessary to bring all future money figures to the present. For example, in a typical benefit/cost analysis of a construction project, one has to compare the current year's construction costs with future years' monetary benefits and maintenance costs. To address these comparisons, we ask the question: "How much is a dollar to be received in the future worth today?" Note that $\$ 1$ received today can be put in a bank to eam interest, at rate $r$ per period. Thus this period's $\$ 1$ will become $\$ 1 \times(1+r)$ at the beginning of next period. Equivalently, $\$ 1$ received at the beginning of the next period is worth only $\$ 1 /(1+r)$ today. By letting $f=1 /(1+r)$, we can see that a payoff of $\pi$ to be received next period is worth only $f \pi$ now. In this terminology, $f \pi$ is the present discounted value today of a payoff of $\pi$ next period. See ROBERT S. PINDYCK \& DANIEL L. RUBinfELD, MiCROECONOMICS 542-45 (5th ed. 2001). 


\section{B. The Case of Unknown Entrant Costs}

In most realistic cases, the incumbent will not know the costs $c_{\text {high }}$ and $s$ of potential entrants who may come along during stage 2. As a consequence, the incumbent monopoly will not know how low it needs to price in order to limit entry. It must guess. In such cases, the incumbent monopoly will generally price lower during stage 1 than under the Brooke Group rule because, in addition to the benefit of increasing current demand, the firm has a new benefit from a price cut that it did not have before: Low stage 1 prices limit entry. (Under the Brooke Group rule, the threat of low prices during stage 2 is sufficient to limit entry.)

Under the proposed rule, the incumbent monopoly will choose a price $p<p_{\text {monop }}$ that balances short-run profits against the long-run profits from entry deterrence. Potential entrants with costs low enough to allow them to enter profitably while pricing at $0.8 p$ will do so and will take advantage of the shelter from the new predation law.

When a low-cost entrant materializes, consumers will get the additional benefit of entry: typically, prices of $0.8 p$, during the price freeze and even lower prices in any subsequent competition beyond stage 2 , when the price freeze is removed. Even if no entrant emerges, consumers will benefit from the incumbent's limit pricing.

This model illustrates the dual advantages of the proposed predation rule: It encourages low pricing to deter entry and simultaneously encourages entry by any firm that can bring substantial value to consumers. What is lost is the potential for immediate, vigorous competition following entry. If significant entry were common without the protection of the price freeze outlined in Part III, then consumers may lose from the new rule. However, in the case of an incumbent that has maintained a large enough market share and has been judged to have sufficient advantages or immunity to satisfy the first prong of the Grinnell monopolization test (monopoly power), getting sufficient entry and getting low prices in the absence of entry are probably the two biggest problems. Vigorous competition after entry seems only an added nicety, one reasonably well addressed by the requirement that the entrant attest to its merit and seriousness by pricing at least twenty percent below the incumbent and showing sufficient capacity to satisfy the demand. A period of limited protection for the entrant may also lead to more serious long-run competition because it may give the entrant time to move along the learning curve and to establish itself in the market.

The model has also demonstrated that low pricing may be anticompetitive even when price exceeds all measures of cost and even when prices are in fact short-run profit-maximizing. 
This observation suggests that courts and commentators should cease their exclusive focus on deviations from short-run maximization as an element of a predation case. Deviations from maximization do suggest that anticompetitive results are apt to materialize in the future and that long-run lessening of competition is what motivates a firm to deviate from profit maximization today. However, low prices can be profit-maximizing and still injurious to competition. If the goal of antitrust is consumer welfare, then the inquiry should focus on that goal, not on whether a firm is maximizing profits in the short run.

\section{COMPARISON WITH OTHER DYNAMIC PREDATION STANDARDS}

As discussed in the Introduction, both Baumol and Williamson have proposed dynamic predatory pricing standards that base liability on comparisons of a firm's behavior over time rather than a comparison of price and cost. They are thus quite similar in spirit to this Essay's proposal.

Baumol proposed that once a firm cuts its price, the price cut should be permanent, so that the firm could not hope to profit later from a higher price. ${ }^{97}$ (Because we live in a dynamic, ever-changing world, he proposes making the price restrictions quasi-permanent.) Like this Essay's rule, Baumol's proposal seeks to prohibit the dynamic pricing pattern of predation-high prices in stage 1 , low prices after entry in stage 2 , and then high prices in stage 3 . The difference is that liability under Baumol's rule is triggered by the price rise in stage 3 rather than the price cut in stage 2 .

Since the principal objective of antitrust law is to keep prices down, Baumol's proposal may seem like an ideal trigger for liability. In fact, however, raising prices has long been considered unproblematic from an antitrust perspective. ${ }^{98}$ This is because the statute bans "monopolization," and high prices do not keep rivals out or promote monopoly; rather, high prices actually invite entry. Since monopolization has historically been interpreted as the exclusion of rivals rather than the enjoyment of monopoly profits, this Essay's proposal has a better legal foundation than Baumol's. The price cut after entry is exclusionary, and using it as the liability trigger is more in line with precedent.

The rule proposed in this Essay also has advantages over Baumol's in terms of economic consequences. First, his rule does not provide the entrant as much protection as this Essay's rule. Although Baumol's rule may sometimes discourage the incumbent from sacrificing in order to drive

97. Baumol, supra note 18.

98. See e.g., 3 AREEDA \& HovenKAMP, supra note 38, II 720a, at 254-55; see also Chi. Profl Sports Ltd. P'ship v. NBA, 95 F.3d 593, 597 (7th Cir. 1996) (overturning a decision that the NBA's telecast fees were too high and noting that "the antitrust laws do not deputize district judges as one-man regulatory agencies"). 
entrants out (because the sacrifice would be quasi-permanent), the incumbent preserves this price-cutting option and may choose to cut prices. If we analyze the model presented in this Essay under Baumol's proposed rule, we find that the incumbent would exercise the price-cutting option during stage 2 and drive the rival from the market, because that action is profit-maximizing and involves no sacrifice. Hence, this Essay's rule encourages more entry at any given stage 1 price, because the price-cutting option disappears.

This Essay's rule also encourages lower stage 1 pricing (limit pricing). Baumol's rule gives the incumbent no incentive to price low in stage 1 to discourage entry because the rule creates no link between stage 2 prices and stage 1 prices. Under Baumol's rule, an entrant's decision will be based upon stage 2 prices (after entry), not stage 1 prices (before entry). In the model analyzed here, Baumol's rule performs exactly like the Brooke Group rule. The incumbent charges monopoly prices during stage 1, the entrant does not enter during stage 2 because it will be undercut if it does, and the incumbent is again left alone in the market during stage 2 , able to charge monopoly prices.

In other settings, Baumol's rule does, of course, have some advantages over the Brooke Group rule. The virtue of Baumol's rule is that if prices are cut by the incumbent in stage 2 , consumers can enjoy low prices on a quasipermanent basis. In some settings, the quasi-permanence of price cuts will lead to more caution and higher incumbent prices in response to entry as compared with the Brooke Group rule. This effect will tend to encourage entry, although less than under this Essay's rule. Again, Baumol's proposal gives no incentive to charge low limit prices during stage 1 , so if entry does not materialize (as it will not in his model), consumers gain nothing from the Baumol rule. The Baumol rule suffers the same problem as Brooke Group: the possibility of continuous high prices without entry. Like the Brooke Group rule, Baumol's rule may encourage more post-entry competition. As this Essay has argued, however, the biggest problems in monopoly markets involve getting low prices before substantial entry and getting substantial entry, not assuring some level of post-entry competition. ${ }^{99}$

Williamson's predation standard is closer to this Essay's proposal: $\mathrm{He}$ proposes prohibiting the incumbent from expanding output for twelve to eighteen months in response to entry. ${ }^{100}$ This rule, like the rule proposed here, encourages lower pricing before entry because reactions are restricted. Williamson's rule also encourages entry because it restricts the incumbent's

99. Moreover, the comparison of post-entry competition is ambiguous, because this Essay's threshold for the price freeze encourages low post-entry pricing.

100. Williamson, supra note 18 , at $294-96$. 
freedom to react. However, neither of these two beneficial effects will be as large under Williamson's rule as under this Essay's rule, because Williamson's rule allows the incumbent to lower prices after entry. Williamson's rule also does not condition protection upon the substantiality of entry (e.g., the entrant offering a twenty percent price discount), so an entrant may be more likely to duck just under the monopoly price umbrella without offering substantial benefits to consumers, as this Essay's rule requires in order to trigger protection.

\section{APPLICATIONS AND REFINEMENTS OF THE PROPOSED PREDATORY PRICING RULE}

Applications of the proposal in Part III will necessarily come less neatly packaged than the model in Part IV. This Part discusses how the proposed predation rule might play out in several concrete settings and argues that, in most of them, the rule has the potential to benefit consumers.

\section{A. Northwest Airlines and Reno Air}

Northwest Airlines has a major hub in Minneapolis-St. Paul. In 1993, it enjoyed a hub premium of $21 \% .^{101}$ Northwest had once serviced the RenoMinneapolis route but had ceased doing so in late 1991. Reno Air began operations in July 1992 and developed routes between Reno and several major West Coast cities. On February 10, 1993, Reno Air announced that on April 1 it would begin three daily nonstop flights between Reno and Minneapolis. This proved to be a big mistake. Reno Air would then be flying from major West Coast cities to Minneapolis in competition with Northwest. On February 11, the next day, Northwest announced that three daily nonstops of its own between Reno and Minneapolis would also begin on April 1. On February 12, Northwest announced that on April 1 it would also begin daily nonstops from Reno to Los Angeles, Seattle, and San Diego-routes that Northwest had not previously served but that competed directly with Reno Air's mini-hub in Reno. Northwest also promised Reno residents bonus frequent flyer miles on these routes and gave travel agents special incentives to book passengers on Northwest. ${ }^{102}$ On February 14 , as a

101. See Severin Borenstein, Presentation to the TRB Study Committee on Airline Competition tbl.2 (Jan. 21, 1999), reprinted in CLINTON V. OSTER, JR. \& JOHN S. STRONG, PREDATORY PRACTICES IN THE US AIRLINE INDUSTRY 33 tbl.6 (2001), http://152.119.239.10/ docimages/pdf59/121516_web.pdf.

102. These incentives, called Travel Agent Commission Overrides, or TACOs, are typically not disclosed to passengers but give agents substantial incentives to steer passenger purchascs. OSTER \& STRONG, supra note 101 , at $8 \mathrm{n} .6$. After objections from the Department of Transportation to the plan of a mini-hub in Reno, Northwest cancelled the continuing flights to the 
Valentine's Day present to Reno Air, Northwest announced fares to match Reno Air's fare from Reno to Minneapolis and also announced sharp fare reductions on nonstop flights between Minneapolis and Los Angeles, San Francisco, San Diego, Seattle, Ontario (California), and Portland, so that fares for these flights were the same as Reno Air's fares for connecting service. (Northwest's fares had been roughly $\$ 200$ to Seattle and $\$ 250$ to the other cities, and it dropped them to roughly $\$ 150$ each way.) Reno Air stubbornly began service on April 1 as planned, but after two months of losses it cut service on the Reno-Minneapolis route to one flight a day on May 20 and none after June 1, 1993. Following Reno's exit, Northwest brought its fares from Minneapolis to the West Coast cities back up over the next few quarters, eventually to levels in excess of what they had been initially ${ }^{103}$ By 1994 Northwest's overall hub premium in Minneapolis had increased to $42 \% .^{104}$

Was Northwest pricing below an appropriate measure of costs as required for predation by Brooke Group? The answer might be simply "no" if $\$ 150$ is above Northwest's fully allocated cost. Alternatively, fully allocated costs could be in excess of $\$ 150$, but it is very difficult to prove in court that $\$ 150$ each way is less than an appropriate measure of variable or marginal cost. There are often good arguments that the marginal cost of an extra passenger could be close to zero (meals plus ticketing plus extra fuel). It seems likely, however, that Northwest's tactics hurt consumers. If Northwest had not responded by entering the Reno-Minneapolis market and had kept fares at $\$ 250$ for direct flights to the West Coast, travelers between Minneapolis and the coast could have chosen between direct flights on Northwest for $\$ 250$ or connecting Reno Air flights for $\$ 150$. True, Minneapolis customers did get a few months of flying direct for $\$ 150$, but ultimately fares rose beyond $\$ 250$. Moreover, hub premiums from Minneapolis increased by $21 \%$ to $42 \%$, which was plausibly due to the demonstration effect of Reno Air. ${ }^{105}$

The proposed Department of Transportation (DOT) enforcement policy for unfair exclusionary practices under its unfair competition statute would create a broader test. DOT would only have to show that Northwest had a dramatic departure from profit maximization (not that it actually lost money) in order for Northwest to be guilty of unfair competition. ${ }^{106}$ But

three West Coast cities from Reno. See Administration Warns Airlines It Will Enforce Federal Antitrust Laws, MINNEAPOLIS-ST. PAUL STAR TRIB., Apr. 5, 1993, at 7A.

103. See OSTER \& STRONG, supra note 101, at 7-9.

104. Oster and Strong's hub premium calculations control for flight mileage and market density. Id. at 32 .

105. It is unclear why Northwest's hub premium went up. Since it is a premium over other fares, general fare increases cannot explain it. Also, other hub premiums did not increase by similar amounts.

106. Enforcement Policy, supra note 12. 
what if Northwest's response was profit-maximizing even in the short run, as in the model of Part IV? Suppose that Northwest made more money in the short run by matching Reno Air's fares and also enjoyed the long-run benefits of both reduced competition on flights to the West Coast and reduced entry on other routes. Are consumers not equally injured regardless of whether Northwest's strategy is profit-maximizing in the long run or in the short run as well? $?^{107}$

Suppose instead that Reno Air could bring a case under this Essay's interpretation of section 2. To do so, Reno Air would point to Northwest's enormous market share of flights between Minneapolis and West Coast cities in order to establish that Northwest was a monopoly. Reno would show that Northwest had monopoly power in its hub ${ }^{108}$ and was able to raise prices $21 \%$ above competitive levels before the predation and $42 \%$ afterward, according to Borenstein's empirical evidence. ${ }^{109}$ Finally, Reno Air would show that it began to serve routes between West Coast cities and Minneapolis at fares $25-40 \%$ below Northwest's average prices. ${ }^{110}$ For many passengers, these fares would probably qualify as $20 \%$ discounts despite the potential quality difference between Northwest and Reno Air, although some evidence on consumer preferences and choices would be helpful on this point.

If these fares did not represent a $20 \%$ quality-adjusted discount, Reno Air probably would have lowered its fares somewhat more-another boon for consumers. Reno Air would have been able to charge these low fares without Northwest's response for twelve to eighteen months, so customers could have enjoyed low fares for much longer than they did. Reno Air might have developed enough of a consumer base that it could compete with Northwest in the long run, as did Southwest Airlines in other markets. If not, Northwest could ultimately respond and drive Reno Air out, but as soon as Northwest raised prices again, Reno Air could return. Each entry

107. If Northwest's costs are sufficiently low, then presumably the $\$ 150$ fares are short-run profit-maximizing.

108. It is an open question whether the relevant market would be the market for travel to and from Minneapolis or between particular city pairs. One reason to think that the relevant market is not city pairs is that it might not be possible for a hypothetical monopoly of a single city pair to raise price above the competitive level. Take, for example, the Reno-Minneapolis route. A monopolist over that route alone could probably not raise price above competitive levels without attracting swift entry and supply substitution from Northwest, which has a relatively easy time flying between Minneapolis and any other city.

109. Borenstein estimates that Northwest's hub premium in Minneapolis was 21\% in 1993 and $42 \%$ in 1994. Borenstein, supra note 101, at tbl.2, reprinted in OSTER \& STRONG, supra note 101, at 33 tbl.6. But see Michael E. Levine, Price Discrimination Without Market Power, 18 YALE J. ON REG. (forthcoming 2002), available at http://papers.ssrn.com/paper.taf? abstract_id=224947 (arguing that high prices in some segments may reflect inelastic market demand and the most efficient way to recover common costs, and should not be used to infer monopoly power).

110. The fare drops of $25-40 \%$ can be inferred from comparing the first and second quarters of 1993. OSTER \& STRONG, supra note 101, at 9 fig.l. 
would likely be profitable because of the protection from the price freeze, in contrast to the losses Reno Air suffered from its actual entry with no legal protection. If Northwest is the more efficient carrier because of the efficiencies of its hub, it would have to charge low prices consistently to keep Reno Air out.

The rhetoric surrounding predatory pricing, and indeed much of antitrust law, has developed in such a way that it seems as if there is a "right" of firms to maximize profits in the short run, and that the law cannot interfere with this "normal" business behavior. There is no obvious reason, though, that Northwest should have the right to respond to Reno's entry if the right to respond means that consumers must pay higher prices than other firms could provide flights for.

\section{B. Vanguard and American Airlines}

The Department of Justice sued American Airlines for its reactions to attempts by Vanguard, Western Pacific, Sun Airlines, and others either to begin passenger service to Dallas-Fort Worth International Airport or to expand services to that airport. Vanguard, for example, began operations in late 1994, and began flying between Kansas City and Dallas-Fort Worth with three daily nonstop round trips on January 30, 1995. ${ }^{11}$ At that time, American operated eight round-trip flights, carrying $65 \%$ of the passengers between Kansas City and Dallas-Fort Worth at an average one-way fare of $\$ 107$ to $\$ 117$, and Delta had six flights. ${ }^{12}$ The district court found that "American matched Vanguard's regular low, unrestricted fares with fares at the same fare level but with a penalty for refunds." ${ }^{113}$ By April 1995, one-way fares had reached $\$ 80$ or lower, according to the Department of Justice. ${ }^{114}$ The fare war apparently drove Delta out early-company officials announced a May 1 exit in February $1995 .{ }^{115}$ According to the district court, "American determined that it would have to choose between a [market] 'share' strategy versus a 'revenue' strategy," and decided to add six more flights to "stand up against Vanguard's service in the market." 116 At that point, Vanguard reduced its service to one round-trip daily. By December 1995, Vanguard had no more nonstop flights between DallasFort Worth and Kansas City.

111. United States v. AMR Corp., 140 F. Supp. 2d 1141, 1155 (D. Kan. 2001).

112. See Complaint II 32, AMR Corp. (No. 99-1180), http://www.usdoj.gov/atr/cases/f2400/ 2438.htm (explaining market share and pricing data).

113. AMR Corp., $140 \mathrm{~F}$. Supp. $2 \mathrm{~d}$ at 1155.

114. The Complaint alleges that American's one-way fare was $\$ 80$ in April 1995. Complaint II 32, AMR Corp. (No. 99-1180), http://www. usdoj.gov/atr/cases/f2400/2438.htm.

115. AMR Corp., 140 F. Supp. $2 \mathrm{~d}$ at 1155.

116. Id. 
Although American's revenues from flying this route were not below its variable cost, American's price cuts made it unprofitable for Vanguard to operate its three flights, and the combination of its price cuts and the addition of extra flights made Vanguard withdraw its last remaining flight by December. American's ability to drive Vanguard from this route without itself suffering the losses that Bork's analysis predicted should come as no surprise, given this Essay's analysis and the likely advantages of American, including lower cost. ${ }^{117}$ "After Vanguard ceased its nonstop DFW-MCI service, American's service dropped to ten daily flights" and its average fares increased from $\$ 75$ to $\$ 100 .^{118}$ Between January 1, 1996, and September 1996, when the next period of predatory pricing allegedly began, American's average fare continued to rise, ranging between $\$ 108$ and $\$ 147 . .^{119}$

In September 1996, Vanguard tried to build a mini-hub in Kansas City, announcing that it would reintroduce nonstop service between Dallas-Fort Worth and Kansas City, and introduce nonstop service between Dallas-Fort Worth and Cincinnati and Phoenix. With a mini-hub and access to DallasFort Worth, Vanguard could take some advantage of the productive and demand-side efficiencies of having a hub, and could potentially share with American the hub premiums on fares from Dallas-Fort Worth to these cities. Within days of Vanguard's announcement, however, American announced an expansion of service to these cities, including new service to Cincinnati, a route it had abandoned in 1994. Vanguard quickly recalculated, and pulled out of the Dallas-Fort Worth-Cincinnati and Dallas-Fort Worth-Phoenix routes in November 1996. Vanguard reduced its service between Dallas-Fort Worth and Kansas City to a single daily nonstop flight in one direction, and a connecting flight and a one-stop flight in the opposite direction. American subsequently raised its fares substantially on these spoke routes. Vanguard moved its mini-hub to Kansas City and eliminated all service to or from Dallas-Fort Worth except for flights from Kansas City.

The district court ruled that American's pricing reactions were perfectly legal because they were not below cost and thus failed to meet the Brooke Group requirements for a predatory pricing case. Moreover, the court roundly rejected the Justice Department's attempt to get around the Brooke Group rule by claiming that the case was about predatory capacity improvements rather than pricing. Although American's increases in the number of flights improved the quality of air travel by improving frequency and reducing crowding in airplanes, the court felt that these extra flights

117. See the discussion of American's advantages supra note 12.

118. AMR Corp., 140 F. Supp. 2d at 1156-57.

119. Id. at 1171 . 
represented increases in quantity that were the flip-side of decreases in price, so that the case was nothing but a predatory pricing case.

Suppose the law took the view advocated in this Essay that price cuts can be unlawfully exclusionary when undertaken by a dominant firm in response to a substantial entry even when prices remain above cost. Since market definition and the definition of monopoly are not the subject of this Essay, let us assume that American Airlines either had or acquired monopoly power, as is necessary for a monopolization case, or had a reasonable prospect of acquiring monopoly power and the specific intent to do so, as is necessary for an attempted monopolization case. (This assumption is not entirely unreasonable given that both Delta and Vanguard ceased all nonstop flights on this route by December 1995.) The remaining element in either charge is therefore the exclusionary act of cutting prices or increasing the number of flights.

Several things are worth noting about this case. The first is that pricing below cost was apparently not necessary to induce exit, contrary to the assertions of Bork and Easterbrook.

Under the rule proposed in this Essay, Vanguard could have priced tickets from Kansas City to Dallas-Fort Worth at \$88 each way in January 1995 to trigger the price freeze. This figure is slightly above the level to which prices ultimately fell and seems a slight disadvantage to customers. However, with the protection of the price freeze, Vanguard probably could have filled its flights and expanded beyond three flights rather than being driven from the market. ${ }^{120}$ Therefore, the low fares could have lasted through 1996 as well, suggesting a net benefit to consumers. (Vanguard would have to keep fares low to maintain the protection from the price freeze.) Passengers would have the option of continuing to fly with American, paying higher fares but enjoying more choice in flight times. Passengers would also gain frequent flyer miles that are presumably more valuable due to American's extensive network. Unlike the model in Part IV, these goods are imperfect substitutes, and Vanguard would not attract all the passengers despite its lower fares. Vanguard would also suffer the disadvantage that Dallas passengers are accustomed to calling American for tickets and may do so by habit even after Vanguard has spent enough on advertising so that passengers have heard of Vanguard. Moreover, many passengers will be nervous about entrusting their safety to an upstart, with or without good reason. Vanguard would have plenty of hurdles even if American did not match its fares.

120. The assumption that Vanguard could have filled its flights so as to be profitable seems reasonable because demand for air travel in this price range appears to be quite price responsive. The court noted that on the Dallas to Wichita route an average price drop from $\$ 105$ to $\$ 70$ was accompanied by a doubling of the number of people who flew the route. Id. at 1157. 
If Vanguard's flights became full, so that some consumers did not have the low-fare choice, and if Vanguard were not moving quickly to accommodate this excess demand, then American would be allowed to respond, but even then it could not do what it actually did: lower prices and increase capacity by so much that Vanguard's planes were too empty to be profitable, forcing Vanguard to cancel its flights. American's license to respond would be limited to passengers whom Vanguard is unable to serve. As it happened, empty flights forced Vanguard to cut back to one flight per day in April 1995 and no flights by December.

With the protection afforded by the proposed rule, Vanguard might have accelerated its plan for a mini-hub in Dallas, rather than immediately abandoning it, as it was forced to do in reality, because American could not have responded immediately. If these routes and others were judged to be separate markets, then American could try to preempt entry with limit pricing. Such limit pricing would give customers benefits in many additional markets, as American would not know where Vanguard might enter; American would have to lower its prices wherever its fares appeared to generate sufficient excess returns that even a firm with Vanguard's disadvantages could think the market profitable.

If American had not been allowed to respond to Vanguard's substantial entry and attempt to build a Dallas hub in late 1996, passengers flying between Dallas-Fort Worth and Wichita, Phoenix, and Cincinnati would have been able to fly at Vanguard's low fares for twelve to eighteen months rather than at the higher fares that American ended up charging after Vanguard exited those spoke routes. After the period of protection ended, these customers presumably would have enjoyed the vigorous competition of American. The worst case scenario would be that Vanguard would be driven from the market at that point rather than immediately, as occurred. Still, this might have meant fifteen to twenty-one months of low fares instead of one or two months. More optimistically, Vanguard could have developed a more loyal customer base, and perhaps expanded its emerging Dallas hub to allow it to compete with American on a more permanent basis. The other important advantage of the proposed rule is that American, fearing all these possible benefits for customers, would be forced to price lower to begin with in order to discourage Vanguard and others from entering. That, too, would benefit consumers. Finally, at any given price American charged, entry would be much more likely under this Essay's rule than under the Brooke Group rule, so passengers could more frequently enjoy the benefits of firms like Vanguard.

One thing the American Airlines case points out is that an incumbent may try to increase quality instead of or in addition to lowering price in reaction to entry. Quality is often more difficult to measure than price (though not when it comes in the form of more convenient flight scheduling 
because of an increase in flights). Where quality is easily monitored, it would be sensible to supplement a price freeze with a quality freeze for a reasonable period of time.

\section{Barry Wright}

Barry Wright was an influential pre-Brooke Group case in which the court held that predatory pricing suits could not be brought when prices exceed all measures of cost. ${ }^{121}$ Although the arguments in this Essay run against Judge Breyer's opinion in Barry Wright, the proposal in this Essay, even if extended, would be unlikely to have changed the result.

Barry was attempting to enter the market for manufacturing mechanical snubbers for use in nuclear power plants, a market dominated by Pacific. ${ }^{122}$ How would Barry have fared under the proposed rule? It seems far from clear that it could have qualified as a substantial entrant. First, Barry never actually got to the point in its development where it could produce snubbers, so it could not avail itself of the automatic price freeze for pricing $20 \%$ below the Pacific monopoly. Pacific did respond by offering Grinnell $5 \%$ to $10 \%$ discounts. ${ }^{123}$ It is unclear, however, whether Pacific initially knew it was responding to Barry's development efforts or to Grinnell's lack of demand. Pacific first offered Grinnell the discounts in August 1976, although it only figured out that Grinnell was trying to help Barry enter later in September 1976. Although Grinnell was tempted to accept Pacific's August offer, Grinnell only bought temporary supplies and continued to hope that Barry would provide a viable second source. After Barry announced in January 1977 that it was nine to thirteen months behind on beginning production (which was supposed to begin in January 1977), Grinnell accepted Pacific's offer. Only later, in May 1997, when Barry appeared even further behind, did Grinnell notify Barry that their dealings were finished.

Since Grinnell purchased over fifty percent of U.S. snubbers, it had a substantial interest in keeping Barry in the market if Barry's entry would have kept prices down. Hence, if Grinnell ultimately gave up on Barry-in part because of Pacific's lower offer but also in part because Barry was behind schedule-we might view this as reasonable evidence that Barry's entry attempts did not in the end rise to a substantial level. Grinnell's interests were not perfectly aligned with snubber consumers generally, but

121. Barry Wright Corp. v. ITT Grinnell Corp., 724 F.2d 227 (1st Cir. 1983).

122. Pacific was the only manufacturer of mechanical snubbers sold in the United States. Because mechanical snubbers were so superior to hydraulic snubbers, Pacific's share of the overall snubber market grew rapidly from $47 \%$ in 1976 , to $83 \%$ in 1977 , to $94 \%$ in 1979 . Id. at 229.

123. The actual discounts were $25 \%$ to $30 \%$ compared to the usual discounts of $20 \%$. Id. 
they were close enough to view Grinnell as a reasonable guardian of consumer welfare and a reasonable judge of the substantiality of Barry's entry in light of the mounting delays.

\section{Cable Television in Sacramento}

Hazlett reviews two recent aborted attempts to enter the cable television market in Sacramento. ${ }^{124}$ In the cable industry, subscriber contracts are sold for prices far in excess of the capital expenditure required to get them, suggesting that incumbents generally have substantial market power. Each of the entrants chose a neighborhood in which it planned to compete with the incumbent. The incumbent, which had ample warning of the entry, began "remarketing" these areas and signing up new subscribers at steep discounts, often with several months free. As an additional lure, the incumbent offered customers a price-matching guarantee, promising not to be undersold. Whether the incumbent's prices were below its variable cost is unclear. By the time the entrants could begin marketing, however, there were few customers left who were interested in cable even at very low prices. As a result, even the better-financed entrant was forced to abandon its investment (the worse-financed entrant was bought out).

How would this scenario be treated under the proposed rule? The incumbent offered discounts as entrants began construction, even before the entrants began marketing their services. Therefore, the question is whether the entrants should be counted as "substantial" and thus trigger the price freeze. Neither entrant met the straightforward twenty percent test, but on the other hand, neither had a chance to do so. A reasonable criterion, then, for judging the substantiality of the entry would be whether the construction plans for laying cable would provide service to most houses in the neighborhoods. If they did, then the entry should be judged substantial, at least provisionally. The incumbent should be unable to respond at first, but if the entrant fails to price at least twenty percent below the incumbent when it ultimately begins marketing, then protection should cease, in the same way that protection should cease if the entrant starts out undercutting the incumbent by twenty percent and then quickly raises its price. Two critical differences emerge between this incumbent's preemptive price cut and the one in Barry Wright. In that case, Pacific may not have known of Barry's entry when it first offered the price cut, and Barry Wright's later delays made it seem an insubstantial entrant. Grinnell's decision to abandon Barry supports this inference.

124. Thomas W. Hazlett, Predation in Local Cable TV Markets, 40 ANTITRUST BULL. 609 (1995) 


\section{E. Microsoft and Netscape}

Consider the situation that gave rise to United States $v$. Microsoft Corp. ${ }^{125}$ Netscape created and marketed an Internet browser, giving the browser away to some users and selling it to others. Microsoft was concerned that the Netscape browser and Java, which came with it, both had application program interfaces (APIs) that could ultimately challenge Microsoft's Windows operating system. Microsoft therefore created a rival browser, which it initially gave away for free or in many cases even paid OEMs to install. Netscape began to give away its browser to all users, effectively cutting its price in response to Microsoft. One therefore wonders: Could Netscape be liable for predation under this Essay's rule? That would surely be a perverse result.

Netscape probably did not have monopoly power in browsers, so this Essay's rule would not apply. The government failed to show that browsers were a relevant market. Even if Netscape had the only browser for a short while, it is doubtful that the company had much power over price, and Microsoft's entry would have been assured if Netscape priced too high (and probably was assured regardless). Netscape might in fact have used this Essay's rule to its own advantage by charging that Microsoft had a monopoly in the market for APIs and that Microsoft responded to Netscape's substantial entry in that market by introducing its own new browser and its own Java APIs for free.

\section{CONCLUSION}

This Essay has refocused the predatory pricing debate on ex ante incentives-i.e., the incentives for entry and limit pricing before the predatory period-instead of the traditional focus of high prices after the predatory period. Ideally, a monopoly incumbent should price reasonably low, and in the event that it prices high, other firms should enter the market. The difficulty arises when the entrants have higher costs than the incumbent and expect to be out-competed upon entry. Consumers would then be worse off than if the monopoly firm did not exist, because they would have to pay higher prices than entrants would charge if they entered.

Monopolies that cut prices dramatically in response to entry are exclusionary because the behavior discourages entry. This observation holds even if they are only matching rivals' prices, and even if they are charging prices that exceed their costs. If courts view such behavior as monopolization under section 2 of the Sherman Act, monopolies will price lower than they do now under the Brooke Group rule.

125. 253 F.3d 34 (D.C. Cir. 2001 ). 
Likewise, it is exclusionary for an incumbent monopoly to respond to entry by substantially improving product quality, as when a monopoly airline increases flight frequency. This behavior is no less exclusionary when the product remains priced above cost, as in the AMR Corp. case. If such behavior constitutes monopolization under section 2 of the Sherman Act, monopolies will provide higher-quality products than they do now under the Brooke Group rule.

The courts have two choices about how to recognize above-cost price cuts and quality enhancements as exclusionary. The Supreme Court could simply overrule Brooke Group. A more moderate approach in the lower courts would distinguish the monopoly cases at issue in this Essay from oligopoly cases like Brooke Group. ${ }^{126}$ As this Essay has pointed out, a monopoly typically has substantial advantages that allow it to drive out entrants without incurring losses, a possibility that is less plausible in oligopoly cases like Brooke Group.

This Essay's predation rule essentially makes the market more contestable. ${ }^{127}$ A contestable market behaves like a competitive market even when only one incumbent serves the market, because competitors wait in the wings to enter if the incumbent prices high. The great advantage of a contestable market is that low prices are ensured by the decisions of market participants. No regulator needs to know the costs of other firms, and, in fact, firms do not need to know other firms' costs. The market price is never high, because if it were, competitors would enter and drive it down. Certainly, recognizing a new category of above-cost predation would not make markets perfectly contestable, but it would make markets more contestable.

This Essay's arguments are strongest in the core case, with homogeneous products, a cost advantage for the incumbent, and a clear understanding of what constitutes substantial entry. Substantial administrative difficulties arise when products are differentiated by quality or other characteristics, when entrants are difficult to identify, or when it is difficult to tell whether the incumbent is reacting after rather than before the entrant has materialized. This Essay only briefly mentioned some of these complexities but suggested as an example that if the overall deal offered by an entrant seems comparable to a twenty percent discount on the incumbent's product, the entrants would qualify as substantial and warrant some protection. Such a standard, however, is easier to state than to implement carefully. The variety of potential administrative difficulties is

126. A lower court risks being overturned on appeal because Brooke Group contains dicta stating that the predation standard under section 2 of the Sherman Act is the same as that under the Robinson-Patman Act. Brooke Group Ltd. v. Brown \& Williamson Tobacco Corp., 509 U.S. 209, 222 (1993).

127. See BAUMOL ET AL., supra note 82. 
daunting indeed, but the same is true in other antitrust cases. How is the court to know, for example, whether a merger will or will not be anticompetitive?

The Essay has not dealt further with administrative complexities, because to do so in advance would yield limited insights. Such questions are best faced as they come before the courts. Hopefully, this Essay has at least made clear that low prices can harm consumers and also lower total welfare even if prices exceed cost - a possibility that one sees most clearly by focusing on ex ante incentives to enter the market.

The principal substantive objection to the rule proposed here is that it protects inefficient entrants. Why would we want inefficient firms in the market, and what business is it of antitrust to protect them? The best answer is that consumers often need inefficient entrants. Recall that the entrant only receives any protection if it is a "substantial entrant," which I suggest operationalizing as one pricing at least twenty percent below the incumbent. Only entrants who provide substantial benefits to consumers receive any protection. From the vantage point of overall wealth maximization, the advantages of this rule are ambiguous if the incumbent does not charge low enough limit prices to bar all entry, because some less efficient firms may enter. ${ }^{128}$ Consumer benefits are more certain, however, since limit pricing is encouraged; and at any given incumbent price level, entry is encouraged. Conditional upon entry, the entrant has a strong incentive to price twenty percent below the incumbent instead of ducking just under the monopoly price umbrella. Courts that favor total welfare maximization over maximizing consumer benefits could modify the proposed rule appropriately. ${ }^{129}$

128. The lower prices improve overall welfare, but the higher cost of production lowers welfase. The net result can be ambiguous in general. When limit pricing is perfect and prevents all higher-cost rivals from entering, as in the model here, then overall welfare is improved by this Essay's rule.

129. Such courts might modify the standard of substantiality of entry that a plaintiff must demonstrate; instead of the entrant showing merely that its discount was substantial enough to bring consumers large benefits, the entrant might also be required to show that its costs were sufficiently low that its entry increased total welfare. 
HeinOnline -- 111 Yale L.J. 992 2001-2002

Imaged with the Permission of Yale Law Journal 